\title{
norden
}

\section{Moving towards a circular economy}

- successful Nordic business models

/Policy brief 
(C) Nordic Council of Ministers, 2015

ISBN 978-92-893-4330-5 (PRINT)

ISBN 978-92-893-4331-2 (PDF)

http://dx.doi.org/10.6027/ANP2015-771

ANP 2015:771

(C) Nordic Council of Ministers 2015

Layout: Peter Daniel Olsen

Cover photo: imagesubscription.com

Photo: norden.org \& imagesubscription.com

Print: Rosendahls-Schultz Grafisk

Copies: 50

Typeface: Meta LF

Paper: Munken Polar

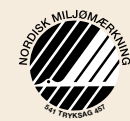

Printed in Denmark

This publication has been published with financial support by the Nordic Council of Ministers. However, the contents of this publication do not necessarily reflect the views, policies or recom-mendations of the Nordic Council of Ministers.

www.norden.org/nordpub

\section{Nordic co-operation}

Nordic co-operation is one of the world's most extensive forms of regional collaboration, involving Denmark, Finland, Iceland, Norway, Sweden, and the Faroe Islands, Greenland, and Åland.

Nordic co-operation has firm traditions in politics, the economy, and culture. It plays an important role in European and international collaboration, and aims at creating a strong Nordic community in a strong Europe.

Nordic co-operation seeks to safeguard Nordic and regional interests and principles in the global community. Common Nordic values help the region solidify its position as one of the world's most innovative and competitive.

\section{Nordic Council of Ministers}

Ved Stranden 18

DK-1061 Copenhagen K

Telefon (+45) 33960200

www.norden.org 


\section{Moving towards a circular economy}

Policy brief

Authors:

Nikola Kiørboe (Copenhagen Resource Institute) Helena Sramkova (Copenhagen Resource Institute)

Mads Krarup (Copenhagen Resource Institute)

With contributions from:

David McKinnon (Copenhagen Resource Institute)

Lars Mortensen (Copenhagen Iris)

Olav Skogesal (Mepex)

Peter Sundt (Mepex)

Oksana Mont (IIIEE)

Circular Business models in the Nordic countries

Nordic examples of business models for the circular economy 6

The workshop $\quad 44$

Key Findings $\quad 46$

Dansk sammenfatning $\quad 54$

References $\quad 57$

Annex 1 - Workshop programme 58

Annex 2 - List of participants $\quad 59$ 


\section{Circular Business models in the Nordic countries - case presentations and policy recommendations}

The concept of a 'Circular Economy' is currently high on the political agenda. World business leaders, policy makers, academics and NGOs argue that a move towards a more circular economy is necessary in order to help solve global environmental and economic challenges. Further, the European Commission has committed to a revised and more ambitious strategy on circular economy before the end of 2015 .

The necessity of a circular economy has been highlighted by many, but perhaps most convincingly by the Ellen McArthur foundation. According to the foundation, the current linear economic model, which is largely based on a production and consumption pattern of "take-makeuse-dispose", has proven unsustainable and has many shortcomings, including a tendency toward shorter product lifespans and a tendency towards disposal rather than repair at the end of the first useful lifespan, even when reuse is possible. The linear model results in inefficient use of our scarce resources, increases harmful emissions and generates increasing amounts of waste from the whole value chain, including resource extraction, manufacturing, transportation and consumption.

The Ellen McArthur foundation describes the circular economy as a system that is restorative or regenerative by intention and design that can be achieved by eliminating waste through the superior design of materials, products, systems, and, within this, business models. In addition to the much more efficient use of resources and thus reduction or even elimination of the negative consequences related to waste generation, the circular economy is also expected to create jobs.

The business case for a circular economy is compelling. Studies show that the global economy could benefit immensely from a more circular approach, embodied by material savings, emissions reductions and job creation. Many large companies in the Nordic countries are already taking ambitious and important steps towards more circular business models, while smaller and sometimes lesser-known companies are already making it happen. By presenting a range of different examples of Nordic businesses, which are making the circular economy happen, the following catalogue is intended to inspire and encourage businesses to make creative and innovative steps in the same direction.

\section{Nordic co-operation for the Circular Economy}

The Nordic Waste Prevention Group under the Nordic Council of Ministers initiated this project named "Moving towards a circular economy successful Nordic business models". The overall objective is to make the circular economy-thinking more mainstream in the Nordic countries and hereby accelerate the development of circular economy in the Nordic countries. 
The project consisted of two activities:

- The organisation of a large multistakeholder workshop with a wide range of actors relevant for the circular economy, which was held in Copenhagen in April 2015.

- The release of a report including a case-catalogue containing eighteen examples of Nordic businesses, which are part of the Nordic circular economy as well as short policy recommendations, which were suggested at the workshop.

These eighteen case presentations are presented in the following section of this report. In addition, the workshop is documented and summarized in the final section and in the annexes.

\section{Instruments needed for the transition to a circular economy}

In summary, in order to make the circular economy-thinking more mainstream and in order to accelerate the development of circular economy in the Nordic countries, the workshop discussions led to the following overall policy recommendations:
- In general, governments should impose simple and long-term objectives and regulations, which level the playing-field for all actors.

- Governments should set re-use targets.

- Governments should enable and support better quality in recycling.

- Governments should utilize public procurement as an active tool in creating markets and demand for circular business models.

- Governments should set legal requirements for reparability, demanding longer product warranties and better information.

\section{Further, there was general consensus that:}

- producers should improve on circularity by designing products for long life including design for reuse and repair,

- a certification scheme for reused and repaired products would improve markets for these types of products, and that

- improved communication and transparency via best-practice presentations, mentor schemes and increased dialogue would help generating the general knowledge- and information flow, which is needed.

\section{Finally, it was recommended that the Nordic Council of Ministers should:}

- identify sectors or areas that are most relevant for circular economic business models,

- demonstrate incentives (monetary as well as non-monetary) which can pull (rather than push) development towards a circular economy,

- explore and develop National Capital Accounting in order to "get the prices right",

- explore the possibilities of redefining end-of-waste criteria in European legislation in order to ease possibilities for reuse, repair and refurbishment, and

- coordinate and spread the voice of the Nordic countries in clear messages, with a view to e.g. influence the European development within the environment and circular economy. 


\section{Nordic examples of business models for the circular economy}

The following examples from the Nordic countries showcase a range of inspiring and successful implementations of circular economy in practice. The examples cover a wide range of business types and business models, but particular focus has been placed on business models that prevent the generation of waste. Waste prevention is a top priority in both Nordic countries and in the EU, and is a central part of the circular economic model. However, once inevitable waste has been generated, circular business models can help close material loops as efficiently as possible.

The examples have been grouped under the following categories:

- Product design

- Service- and function based models

- Collaborative consumption

- Reuse

- Repair

- Recycling and waste management
Further, the examples have been identified mainly from areas in which the Nordic countries have prioritised their waste prevention programmes as well as areas identified as having high environmental impact. These sectors are:

- Food

- Textiles

- Electric and electronic equipment (EEE)

- Building, construction and demolition

- Furniture

- Packaging
A few interesting examples covering other sectors have also been included for additional inspiration.

The examples are described only briefly, and are merely presented in order to inspire and create new ways of thinking in the Nordic business community. They are predominantly based on publicly available information, which in some cases has been supplemented with in-depth interviews with persons from within the business. No social-, environmentalnor economic assessment has been conducted. 


\begin{tabular}{|llll|}
\hline Company & Country & Sector & Business model \\
\hline Agito Medical & DK & EEE & Repair \\
\hline Norsk Ombruk & NO & EEE & Reuse and Repair \\
\hline Godsinlösen & SE & EEE & Repair \\
\hline Xella Danmark & DK & Building and C\&D & Product design \\
\hline Houdini Sportswear & SE & Textile & Product design, Service and function, Reuse, Repair \\
\hline Icelandic recycling fund & IS & Textile & Recycling and waste management \\
\hline Vigga & DK & Textile & Design, Service and function, Reuse \\
\hline Arla Foods & DK & Food & Product design, Recycling and waste management \\
\hline Matsentralen & NO & Food & Service and function \\
\hline Martela Oyj & FI & Furniture & Product design, Service and function, Reuse, Repair \\
\hline GH Form & FK & Furniture & Service and function \\
\hline Off2Off & Furniture & Reuse \\
\hline Repack & SE & Packaging & Reuse \\
\hline Plus Pack & FI & Packaging & Product design \\
\hline Lassila \& Tikanoja Plc & FI & Packaging & Reuse and Repair \\
\hline Blocket & SE & Other & Collaborative consumption, Reuse \\
\hline Zen Robotics & Other & Recycling and waste management \\
\hline Norsk Gjenvinning & Other & Recycling and waste management \\
\hline & & & \\
\hline
\end{tabular}




\section{Agito Medical}

\section{Providing life-changing medical equipment}

As European hospitals and clinics renew their medical and laboratory equipment and dispose of old items, many hospitals in other parts of the world cannot afford to purchase much-needed equipment. Agito Medical connects these two communities in a circular business model, by retrieving old equipment from one and making it available to the other.

\section{Extending products' life-time}

Agito Medical, founded in 2004, is Europe's largest provider of preowned medical equipment. The company specialises in purchasing, refurbishing, remarketing and reselling used medical equipment (for example MRI, CT and Ultrasound systems, X-ray, etc.). Co-operating with medical equipment manufacturers (OEMs), clinics, hospitals and laboratories worldwide, Agito Medical maintains an online database of available equipment and spare parts, which its clients can use to find exactly what they need at a lower price than the cost of brand new products.

This circular business model secures an extended lifespan of the equipment through re-using what would otherwise be discarded. In particular the refurbished equipment is an affordable alternative to new equipment for less privileged customers. Agito Medical provides turn-key solutions, including shipping and installation of the equipment and removal of old equipment.

\section{Service support and}

\section{maintenance}

Aside from direct sales, Agito Medical offers service contracts on $\mathrm{CT}$ and MRI equipment, such as delivering spare parts and engineering maintenance services. Thereby equipment may be repaired and upgraded, rather than replaced. The flexibility of these services secure a maximum possible uptime of the equipment, and prolongs the lifespan of the entire system and prevents waste.

\section{Mobile Rental Solutions}

A fleet of equipped mobile trailers equipped with imaging solutions can be sent to hospitals and clinics to help deal with fluctuating patient flows. These flexible, temporary digital imaging services can be provided where and when needed, reducing both the expenses and the environmental impact of outright purchase of medical equipment that would not be fully utilised. 


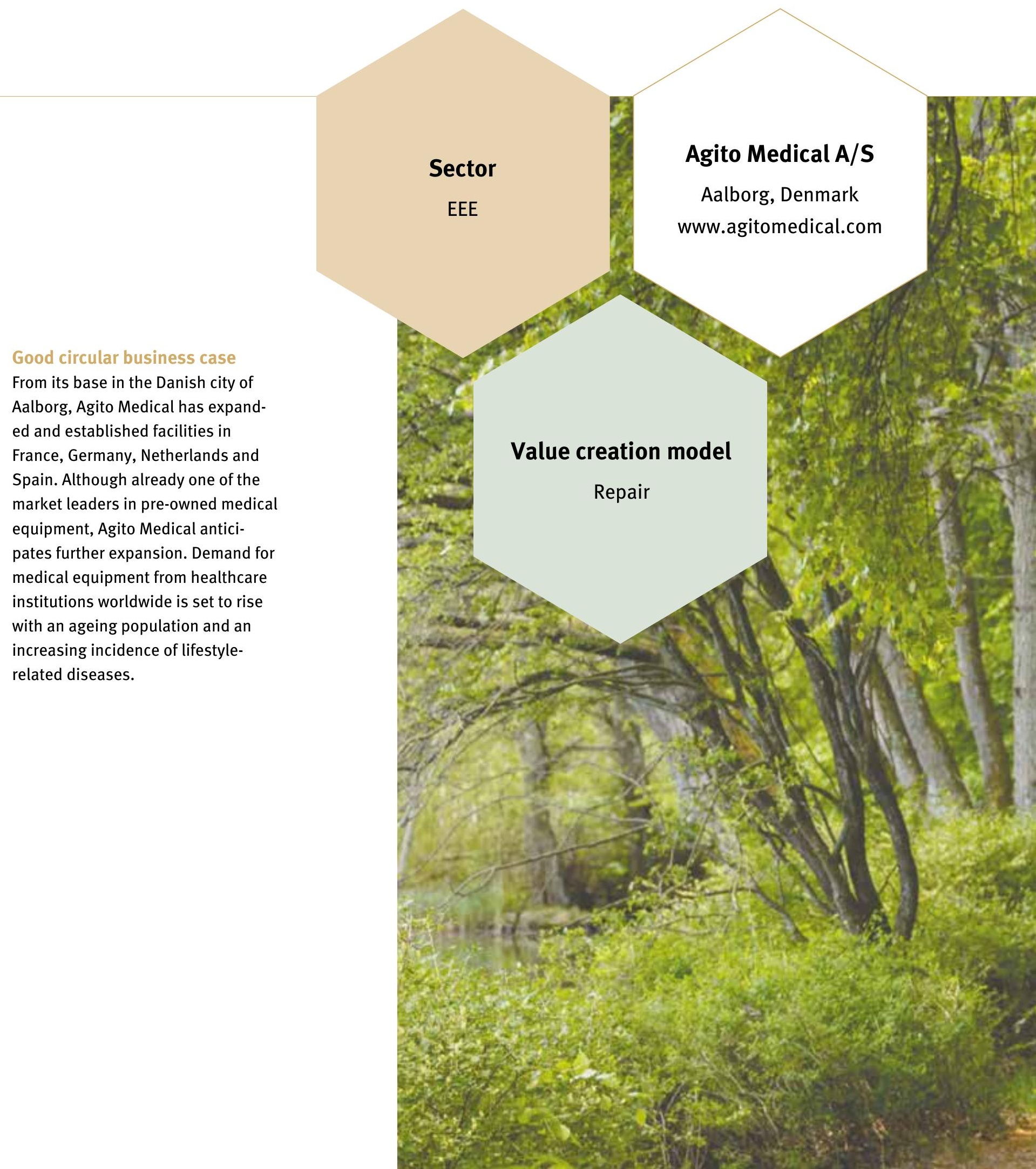


The small Norwegian business Norsk Ombruk has developed a professional and fast growing business model for repair and re-sale of used large household equipment such as freezers, fridges, stoves, washing machines.

\section{Serious business is the key to success}

The reuse market is generally growing in Norway. Reuse of used household equipment is widespread in Norway but is mainly performed by direct sale via the internet or in many cases by the informal sector, unlicensed companies or individuals. Norsk Ombruk has therefore succeeded in building a reliable and robust business concept in collaboration with the retailers and take back systems for large household appliances. With its 12 full-time employees Norsk Ombruk processes about 6.000 units for reuse per year and has a turnover of about 10 mill. NOK. The company also import new equipment for sale.

The business model is structured around a few simple but effective elements:

- Effective logistic with tracking of individual products from collection points, through the repair process along to the end customer.

- Agreement with one of the largest WEEE take back systems in Norway (ERP Norway)

- Collection agreements with selected electrical retailers and municipal collection sites.

- A modern repair facility with skilled staff and established test- and repair procedures and checklists.

- Customer networks of second hand shops for used large household equipment.

\section{Beneficial for environment and economy}

There is particular focus on reusing relatively new, and thus also energy-efficient products, which will ensure environmental benefits. The products which are taken in for reuse will have many years of remaining lifetime and only minor needs for further repair.

Reused products are cheaper than their new counterparts, so are also more economically accessible for many people, particularly those on a tight budget. As long as the business operates by law, jobs are created for the benefit of society as a whole.

A number of other Nordic companies - including Swedish greentech, Norwegian ATEA and Danish refurb all provides a similar service where they take in used IT equipment for repair, and re-sell. 


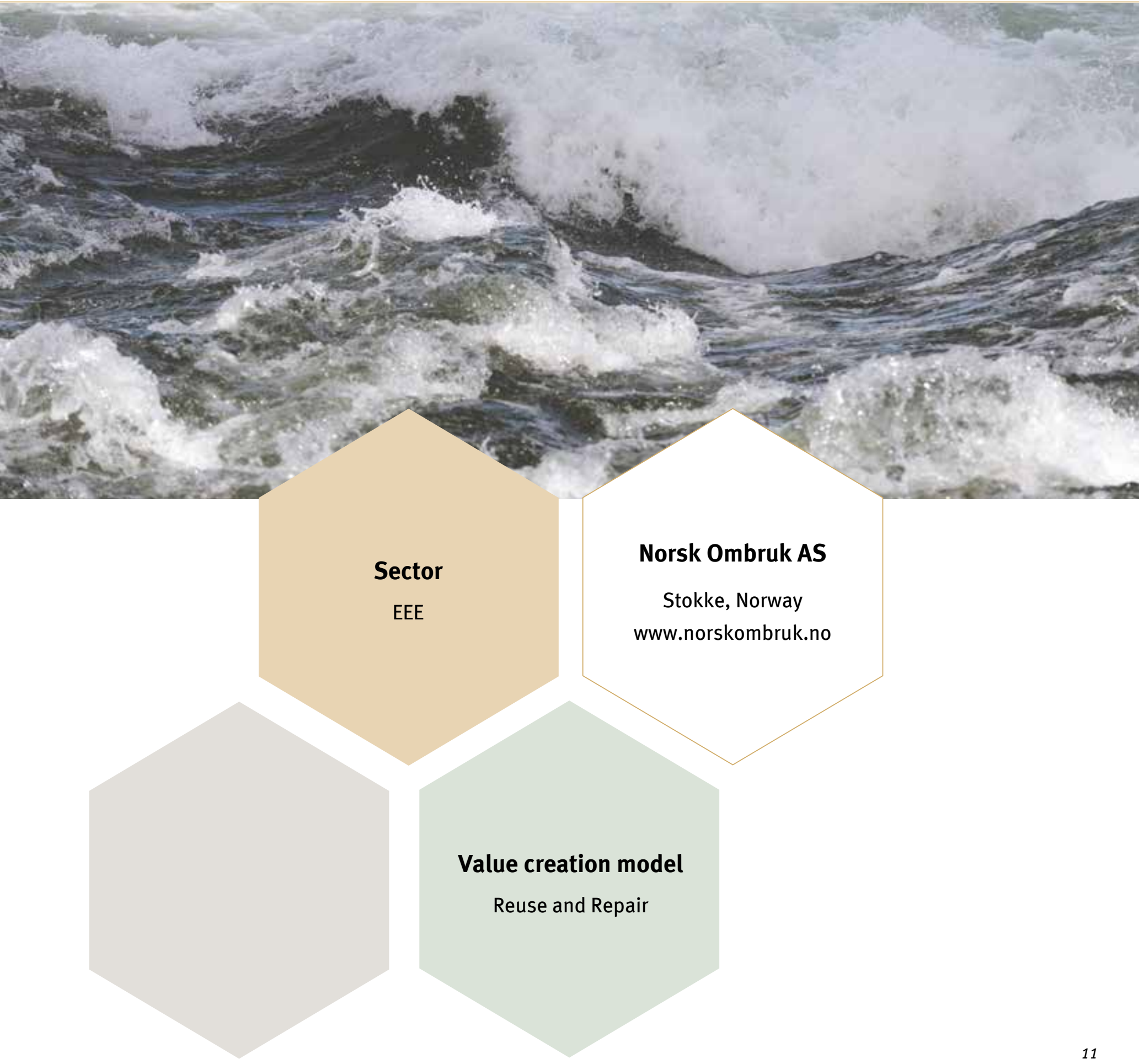




\section{Turning unwelcome accidents into environmental efficiency}

When accidents happen replacement or reimbursement through an insurance policy is a welcome relief. But what happens afterwards to the damaged belongings? Back in 2012 two Swedish entrepreneurs found a business opportunity in redeeming goods in general and damaged electronics in particular. They discovered that while such goods may be useless to insurance policyholders, up to $90 \%$ of all modern electronic devices can be refurbished or renewed.

\section{B2B collaboration}

The business model Godsinlösen rose, and now recycles and resells damaged insured goods, operating in collaboration with insurance companies and policy holders. On request by insurance companies, Godsinlösen retrieves damaged goods from policyholders and ensures that they are handled, by being either reused or recycled, as effective and transparent as possible in line with environmental standards. This service not only generates immediate economic gains but also has a positive effect on the environment. Reuse reduces resource use and emissions linked to manufacturing of new goods.

\section{Resale outlet}

Redeemable goods are sold in Returhuset, a retail store owned by the company. A large share of the goods are portable electronics like mobile phones, laptops and tablets. The net income from this aftermarket is shared between the insurance company and Godsinlösen. This business model thus allows the service provided by Godsinlösen to be mainly self-financed, and often creates a profit to the insurance company.

\section{Massive savings are achieved}

The company has been established on the principle of circularity. All activities aim to close material loops by repairing EEEs. There are several large and small companies on the market, which offer similar services of EEE repair, but not many work directly with insurance companies. The staggering global demand for mobile phones upkeep a high demand for precious metals used in fabrication. Godsinlösen claims to save $27 \mathrm{~kg}$ of $\mathrm{CO}_{2}$ emissions per reused mobile phone. Since inception in 2012, the company has saved 47 tonnes of $\mathrm{CO}_{2}$ by selling 416 laptops reclaimed by insurance companies. At this time, Godsinlösens activities are concentrated mainly in Southern Sweden. However, the company has ambitions to expand to Stockholm and Gothenburg, which will entail collaborating with more suppliers of used EEE. 


\section{Sector}

EEE

\section{SWAPping for more value}

An additional service is the Gödsinlosen SWAP, where the insurance company offers a replacement phone rather than repair or cash reimbursements. Swapping the phone with a refurbished phone from Godsinlösen saves time used to administrate a repair and time spent on each insurance claim. It also lessens the risk of fraud. To the claim holder, a cash allotment for a used phone might be less valuable than receiving a refurbished phone.

Danish SA Service delivers a similar service where they cooperate with ten of the largest insurance companies in Denmark around assessing, repairing and re-delivering damaged white goods.

\section{Godsinlösen Nordic AB}

Staffanstorp, Sverige

www.godsinlosen.se 


\section{Sustainable construction, strong business}

Xella Denmark, part of the international Xella group, produces innovative Autoclaved Aerated Concrete (AAC) blocks which are Cradle-to-Cradle certified. From raw material extraction, through the use phase, and finally as waste, sustainability is a guiding principle in the whole life cycle of their products.

\section{Big scale, minimal environmental impact}

Xella supplies building materials made of AAC and limestone under the names of Ytong and Silka. As the corporation counts some 6.700 employees, a turnover close to 200 mio Eur, 98 factories located in 20 countries and sales representatives in $\mathbf{3 0}$ more, minimising the environmental impacts of both the sourcing of raw materials and transportation of products to customers has a grand impact. The inorganic raw materials - limestone, sand and water - are sourced within a $200 \mathrm{~km}$ radius of each factory.

\section{New business in certified concrete}

Compliant with the strict new 2020 European building standards, the Ytong Energy+ AAC block was developed and Cradle-to-Cradle Basic certified in 2011 . It is $100 \%$ recyclable into new products. Thanks to good insulation capabilities, it enables the building of energy-neutral houses. After the $\mathrm{C} 2 \mathrm{C}$ certification and introduction of Ytong Energy+ on the market, Xella's turnover in Scandinavia has doubled since 2011.

\section{Re-use and re-cycling in all product life-cycle stages}

The circularity of Xella's business model consists in the many re-use and recycling possibilities during the whole life cycle of AAC blocks. In the production phase, lime slurry, a waste product from the production of limestone, is used as a source of energy for the production of AAC blocks. The produced energy more than covers Xella's needs and excess energy is sold on the market. Production waste is collected, dispersed in water or used for the production of new blocks. Moreover, up to $88 \%$ of water vapour used in hardening the blocks is re-used, while percolate is used as process water for facility heating. Finished AAC blocks are transported to construction sites on re-usable wooden pallets and covered in recyclable plastic wrapping. In addition, all construction cut-offs as well as all demolition material at the end of life of the buildings can be transported back to Xella's factory and be used for the production of new AAC blocks. 


\section{Sector}

Building, construction and development

\section{Xella Danmark A/S}

Løsning, Denmark

www.ytong.com

\section{Nothing is wasted}

The environmental and economic benefits of Xella's business model in both operations and the future product offerings of Ytong and Silka building materials, is more than good business. Xella calculates that a family house built using its products will save $10-15$ tons $\mathrm{CO}_{2}$ over 70 years and will benefit from $5 \%$ lower energy consumption every year thanks to the insulating ability of the materials.

As such recyclable building materials become ever more popular, economic as well as environmental savings are realized by both customers and the company.

\section{Value creation model}

\section{Product design}




\section{Houdini Sportswear}

\section{Keeping the great outdoors great}

For Swedish sportswear manufacturer Houdini, creating responsible and sustainable products is the all-encompassing raison d'etre of their product design. Lotta Giornofelice established Houdini in 1993 , wanting to make technical products with a 'less is more' philosophy. The result is a multitude of sustainability initiatives.

\section{Sustainability in the entire value chain}

Houdini's holistic approach to sustainability pivots the Re-project, which encompasses the initiatives Rent, Repair, Recycle and Reuse. Houdini offers rental of shell garments, repair services, recy- cling of old garments and second hand sales, all aimed at prolonged product lifetimes or once worn out, creating new products from the used ones. In 1995, a life-time repair service was launched in order to make Houdini garments last as long as possible.

Since the early days, Houdini has focused on using the "right" fibres in terms of both sustainability and longevity. In 2006 Houdini partnered with Teijin in the closed-loop polyester recycling system Eco Circle $\circledast$ and by 2007 they sold the first sustainable labelled Houdini products made from recycled fibres. Houdini has also sought to reduce the number of suppliers in favour of maintained control as well as on designing products to be "simple" with a limited mix of different materials in order to improve on recyclability. To reduce waste levels, Houdini created the Scrap Me Up project in 2010, which use scrap fabrics from factories to manufacture limited editions.

\section{Rent or buy second hand}

Houdini gear can also be rented. This is an advantage for those who only use shells a few weeks of the year and for those who are not entirely sure which type of shell garment that they want. This is also an advantage for the environment, since garments are not left hanging unused in the

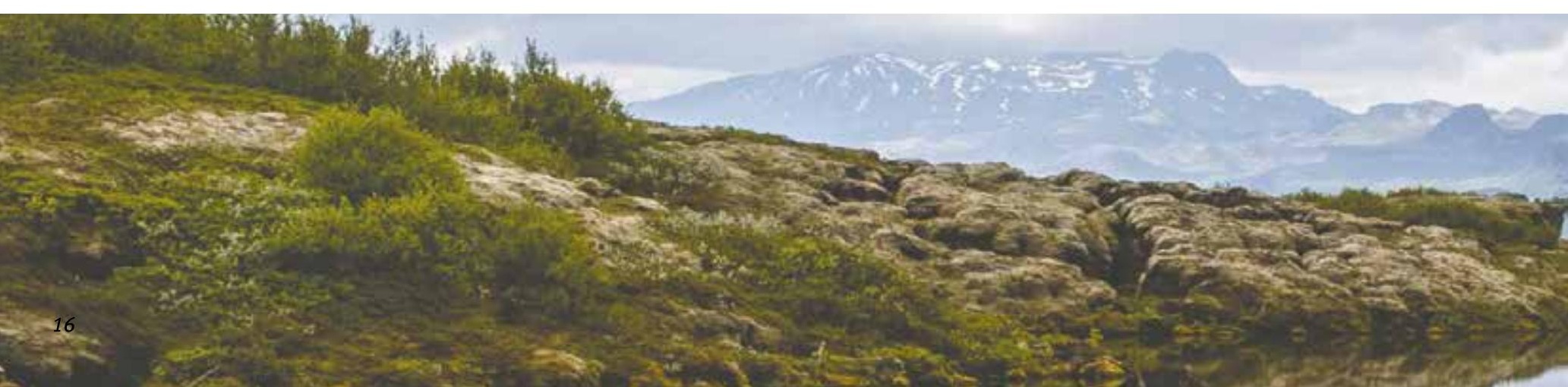


closet. Both entire sets and separate items can be rented for either a weekend or a full week. Houdini stores are also open for resell of second hand Houdini gear. The pricing range from $50-70 \%$ off the price for new items, while the first owner will get $50 \%$ of the second hand sale. When buying a Kids Houdi the customer is offered up to 300 SEK in exchange for a used Houdi garment. The Houdis are then resold in stores for the same prices as was given.

\section{Acclaim and inspiration}

Houdini's efforts have not gone unnoticed. CNBC choose Houdini as one of the 25 most creative European companies in 2010 for its sustain- ability efforts. Houdini also received Swedbank's Sustainability Prize in 2012 for companies able to combine fast and profitable growth with a full on commitment to sustainability.

Other sportswear and clothing companies are also actively pursuing sustainability as a core business goal. Among the most famous are Columbia sportswear, Patagonia and Timberland. In Sweden, other famous examples of a clothes company incorporating sustainability issues in their activities is Boomerang, which takes back their clothes and uses them in furniture upholstering, and Filippa $\mathrm{K}$ which also resells used Filippa K garments in their stores.

\section{Houdini Sportswear AB}

Nacka, Sweden

www.houdinisportswear.com

Sector

Textile

\section{Value creation model}

Product design,

Service and function,

Reuse, Repair 
State-owned Úrvinnslusjóður, the Icelandic Recycling Fund, works through state legislation towards increasing national recovery and recycling rates on various types of products including used fishing nets. Iceland's large fleet of fishing ships discards a great amount of fishing gear each year and the legislation allows the industry to make special agreements with Úrvinnslusjóður in order to ensure collection and recycling of the nets.

\section{Essential collaboration with industry}

Since 2005 Líú, now SFS (Fisheries Iceland), has been responsible for operating and financing a collection system for retired fishing nets based on an agreement with IRF. As long as this agreement is in place, fishing nets made of synthetic materials are exempted from recycling fees.
Fishing is a crucial part of the Icelandic economy generating between $35-40 \%$ of Iceland's GDP. Thus including vessel owners in the system has been a high priority in order to safeguard their mutual interests. The remaining industry was also included, for instance by appointing four out of six board members being from the Úrvinnslusjódur fund.

\section{How it works}

In practice, the vessel owners and crew manually separate the nets from wires and ropes. Hereafter the vessel owners may themselves transport the nets directly to a recycler or pay for transport through the system collection stations. The nets collected in Iceland are mainly transported abroad for final recycling.

\section{The bar is set high}

Úrvinnslusjóður works with clear recycling targets, and is continuously becoming more and more ambitious; from $45 \%$ in 2006 to $50 \%$ in 2007 and $60 \%$ in 2008 . Today the recovery of fishing nets is estimated to be around $80 \%$ and the majority of both nets and wires goes to recycling. Fishing ropes, however, remain difficult to recycle due to the blend of different materials.

\section{A Norwegian pendant}

\subsection{0 tons of plastic equipment} from the fishing and fish farming industry is discarded each year in Norway alone. In Norway, some private and competing schemes have been implemented in order to deal with all this material during the last years. 
Nofir is one of the leading companies recycling discarded equipment from fishing and fish farming recycling, with a nationwide collection system. In 2012 Nofir was granted support from the EU Eco Innovaton scheme and have since collected material all over Europe and lately also in North-America. By 2014 the Norwegian system had collected 4886 tonnes of material, mainly in Norway. Other Norwegian operators report similar good recycling results. Both the Icelandic and the Norwegian systems are simple and could inspire other countries to increase the recycling of fishing nets. Not only does it contribute to reducing resource use but it also helps reduce the amount of fishing equipment discarded in the oceans.

\section{Icelandic Recycling Fund}

\section{Sector}

\section{Textile}

Reykjavik, Iceland www.urvinnslusjodur.is

\section{Nofir AS}

www.nofir.no

\section{Value creation model}

Recycling \&

Waste Management 
Circular economy thinking is the cornerstone of the Danish baby clothes brand Vigga. The business is based on the philosophy, that if a baby romper is only used a few times before your baby outgrows it and the romper then ends up in the attic, almost any effort in sustainable production will most likely be opposed by the rompers short lifetime. Vigga has therefore created a subscription service for baby clothes.

\section{Clothes on demand}

The basic idea is that once the baby is born, you take out a subscription for baby clothes from Vigga. By mail you then receive a pack of selected pieces of clothes for your baby in the suitable size. As your child grows, you then replace the clothes with new packs of Vigga clothes. The smaller sizes are usually only with each user for a short amount of time, because babies grows quickly in the beginning. Larger sizes might thus stay for longer with each baby. However, it all depends on the specific needs of each customer, and it only takes a click on the screen and a visit to the mail box to receive the next size.

\section{Design and quality is crucial}

The Vigga collections are designed to suit all kinds of children in all kinds of shapes. The design is therefore carefully carried out, so that trouser legs and shirt sleeves can be rolled up and down, and necklines are suitable for large heads.
Further, each piece is designed with reuse in mind, and the clothing has been tested to last for the circular business model. The clothing is thus of such a quality that several children can enjoy the clothes. Finally, once the clothes is worn out, the clothes will be used to produce new products, so that nothing is wasted.

\section{Careful attention to production} and social responsibilities

Vigga wears one of the textile industry's most stringent certificates GOTS, which is the acronym for Global Organic Textile Standard. GOTS is an international, recognized labeling system which guarantees that Vigga clothes are made of at least $95 \%$ organic material and that production is both environmentally 


\section{Arla Foods}

\section{Zero waste programme}

Arla Foods is a cooperative dairy company owned by 13500 European dairy farmers, selling food products to consumers in more than 100 countries. Arla is the world's fifth largest dairy company and the world's largest producer of organic dairy products. The company mission is straightforward to secure the highest value for the farmers' milk while creating opportunities for future growth. However, perhaps due to the owner's connection to the earth, achieving 'good' growth, is a big priority.

\section{Environmental strategy}

Arla strives to work responsible throughout the supply chain with their Environmental Strategy 2020, which includes a zero waste vision. Where waste is unavoidable, it is treated as a resource to be reused or recycled. Arla has set three targets to fulfil their vision.
Recyclable packaging, aim to achieve 100 percent recyclable packaging by 2020 by focusing on co-operation with suppliers, researchers and partnerships with key customers, and by evaluating and selecting the right packaging in relation to design and materials. Arla is engaged in development projects for facilitating recycling ex. with the City of Copenhagen to recycle milk cartons and plastics.

Reduce food waste, aim to help consumers bring down their food waste by 50 percent by easier ahead planning in food purchases and through guides in making full use of products, e.g. online tips and tricks for using leftovers, weekly dinner schedules and climate friendly recipes. Another method is optimal packaging in terms of portion size and ability to be completely emptied by consumers. Arla participates in EU's FUSIONS project to reduce food waste through social innovation.
Waste from production, aims to eliminate waste to landfill from production by using waste product for animal feed or biogas production, cooperating with waste management vendors or suppliers to recycle or reuse solid waste. An example is a new developed technology from Arla's Food Ingredients to use leftover acid whey from yoghurt into ingredients for regular food rather than dumps into land farming or feedstock, thereby fine-tuning the value chain and product life cycle.

\section{Other resource strategies}

Arla also has an environmental strategy for water and energy resources, with a 2020 target of $50 \%$ of energy supply from renewable sources, and annual reduction targets of three percent for energy and water consumption in operations and one percent reduction in fuel for transport. Arla's total climate impact has decreased by 12 per cent, compared to 2005 levels, despite increased production. 


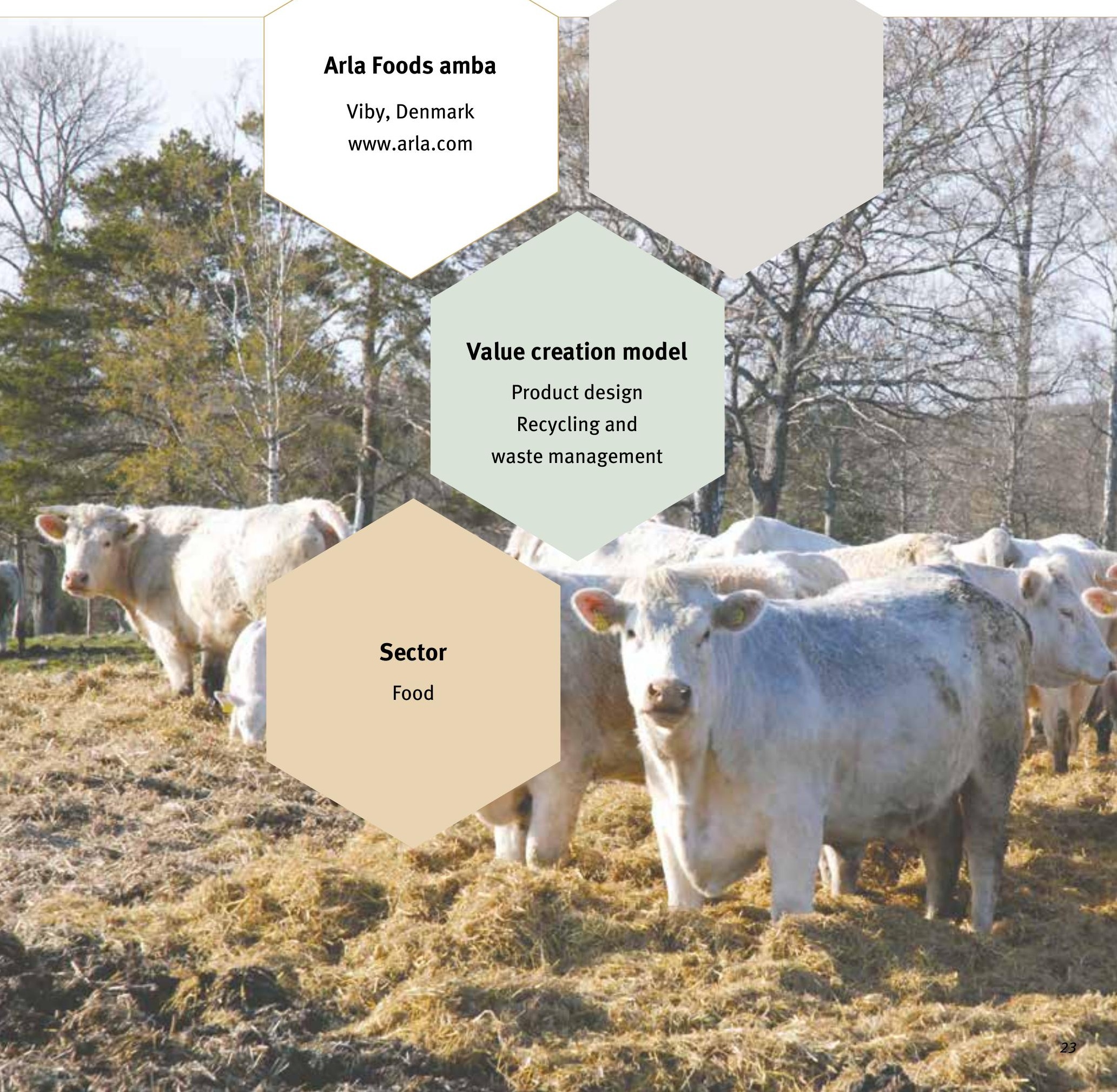


For a multitude of reasons, there is a large amount overstocked and leftover food in Norway, as in other Nordic countries and many other parts of the world. Overstock and leftover food not only represents a financial loss for businesses, but also an environmental problem for society. Increasing pressure from a rising global population and subsequent pressure on land, make more efficient use of food crucial.

While so much food goes to waste, many disadvantaged people cannot afford to buy sufficient nutritious food. Charities estimate that in the Oslo area alone more than 10000 people receive food aid.

Matsentralen - a warehouse for storage and distribution of overstock food and groceries - opened in Oslo in 2013, aiming to help solve these problems by linking food retailers and producers with charities that distribute food to those that require assistance.

\section{Cooperation with charities is the foundation for Matcentralen}

Matsentralen covers around 700 square meters, and is equipped with freezing, refrigerating and a dry storage facilities. Matsentralen accepts food from food retailer and food production companies in the Oslo region. All nonprofit charity organizations can participate in Matsentralen; they can come and collect food from Matsentralen which they can redistribute to disadvantaged people. The food is, of course, free of charge. The concept is inspired by similar initiatives in other European cities and has already created interest in several other Norwegian cities. Matsentralen is organized as a co-operative society, with the Salvation Army as operator together with Blue Cross and the Church City Mission as founders. In 2014 the received food was then allocated (redistributed) to 93 different charity organizations.

\section{Impressive results}

In 2014 Matsentralen received 617 tons of food and groceries from 44 different suppliers. Matsentralen has agreements with most of the grocery and food industry, supermarkets and retailers and Coop Norway, ICA, Norway Group, Asko, Bama, Nortura, TINE and Orkla foods all participate. All revenue comes from sponsors with a 2015 budget of 5,2 million NOK. Matsentralen is run with one full-time employee and three part time volunteers, together with three full-time Fretex employees operating the warehouse.

Danish Fødevarebanken conduct a similar service and in 2013 they provided more than 1 million meals for people in need. 


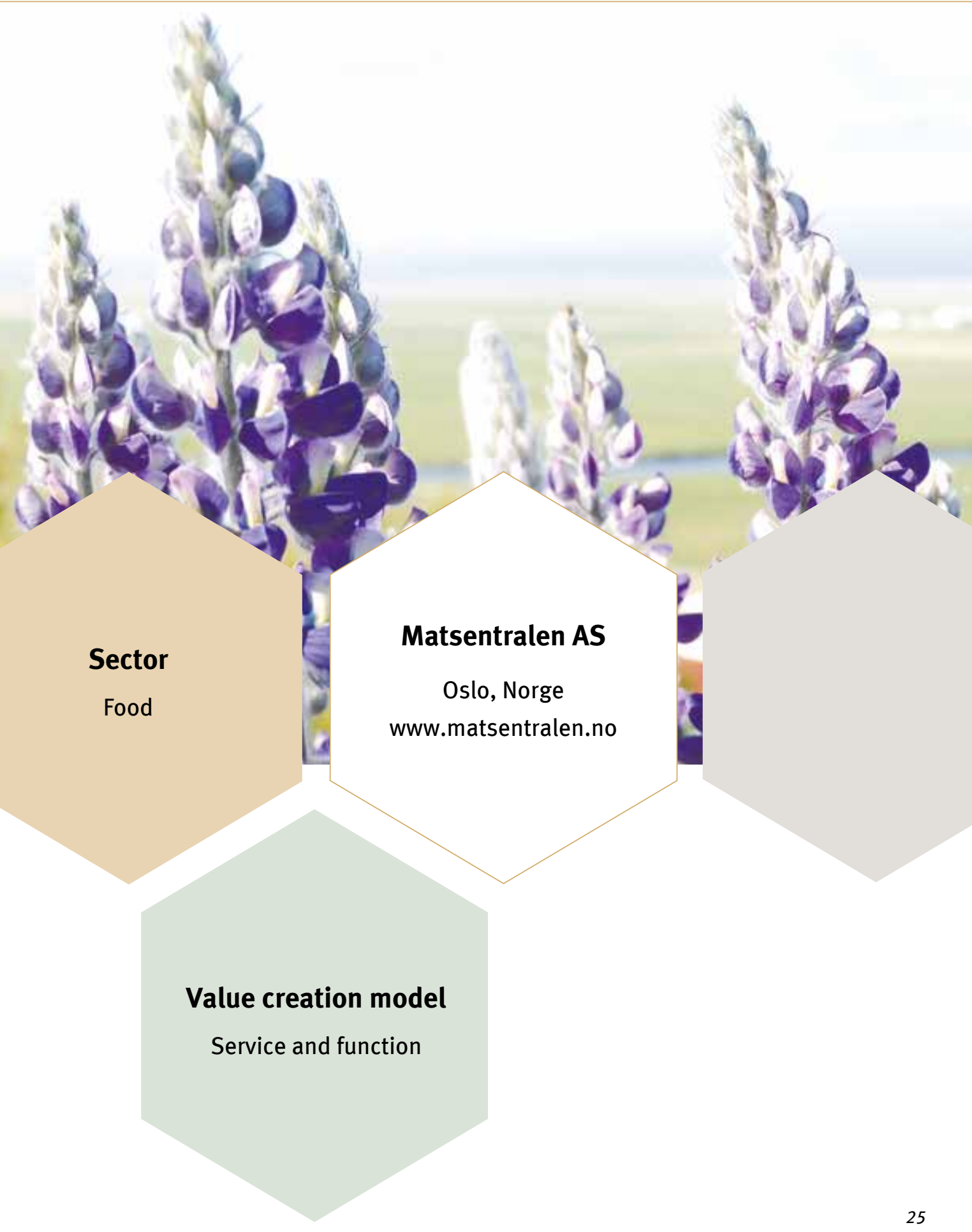


The Finnish company Martela designs and supplies furniture for businesses, public spaces and schools. Their circular business model ensures customers only purchase according to needs; old items are repaired, materials are reused and recycled; and modernising and maintenance is promoted to the highest possible degree, rather than replacing items.

The family company originates in Finland but have quickly evolved to become one of the Nordic leaders in the office interior industry. Its activities have spread widely and in 2014, Martela employed 742 staff in the Nordic countries, Poland and Russia, with a consolidated revenue of EUR 135.9 million.

\section{Environmental at its core}

Martelas Environmental Policy aims to decrease the company's environ- mental impact and promote reuse and recycling. Martela takes responsibility for the total life cycle of their products. From product design and their supply chain, to production and customer service, maintenance service during the use time and finally, when customer no longer needs the product, with product recycling with emphasis in giving furniture a new life. This means that the products are not only designed for the longest possible useful life in terms of materials and design language, but after ended first use, the products can be returned to outlets for repair and recycling.

The company thus not only provide quality furniture in long-lasting design, but they also offer removal services from start to finish, allowing Martela to collect used furniture carefully for intended reuse and refurbishment.
Furniture in the best condition is sold in Martela Outlet stores. Furniture in need of reconditioning, such as office chairs, will be serviced and reupholstered. Almost all materials can be reused. Furniture that is unfit for use will be dismantled and the components sorted into wood, metal and plastic materials. The materials will then be utilised either as parts for used furniture, as secondary raw materials, or in energy production.

\section{Circular solutions for satisfied customers}

Martela supplies furniture to a wide range of businesses such as Finnair, Axfood and PWC. When TeliaSonera, a network- and telecommunication company, created their new office space, Martela provided a circular solution. Existing furniture were relocated and tables were partially altered by shortening their base and replacing their tabletops. However, 


\section{Sector}

\section{Furniture}

the biggest change was carried out on the storage units. Martela cabinets with sliding doors that were originally intended for a single user were modified to make either a shared cabinet for two workstations cabinet with doors or lockers adequate for four users. Martela $R \& D$ designed add-ons suitable for the original structure and modifications were carried out on-site during renovations. This allowed the use of materials to be minimised for reduced environmental impact. 
With raw material costs constituting up to $60 \%$ of the total production expenses, GH Form realized that a lot of money could be saved - both to itself and to its customers - by recycling material rather than using virgin raw material. In fact, in some cases entire products can be recycled, as they are made entirely or mostly of iron. If they are in a good shape, products can even be directly re-used. Perfect circularity.

\section{A park bench as a storage}

\section{for iron}

GH Form produces a wide range of outdoor furniture and other equipment for public spaces, streets, parks, including benches, waste bins, streetlights, bike stands, and plant pots. Many of the products are made from cast iron, which, if correctly maintained, can last for decades. This essentially makes the bench or lamppost a storage for iron: At the end of their life-time, they can be recycled into new products, leading to environmental and economic benefits.
Raw material scarcity brings about increasing material and production prices. It was mainly for this reason that GH Form, founded in 1918 as an iron foundry, adjusted their linear business model into a circular one and started offering products for lease, instead of for sale, to its customers. An example is a recently $\mathrm{C} 2 \mathrm{C}$ certified product, a lamp post, designed to be rented out to municipalities and re-collected after 10 to 15 years, to be re-used or recycled.

\section{How the leasing agreement works}

With a leasing agreement, GH Form remains the owner of the product and makes sure that it remains a part of the circular model. In this way, GH Form offers a service that is fulfilled for a certain time, rather than the product itself. To promote the leasing model, GH Form takes care of all maintenance for the period of the lease. At the end of the lease period, the product is taken back and re-used if no or minor adjustments are required, or dis- mantled and the iron used to cast new products if damaged.

\section{Circularity starts with sourcing}

GH Form aims for highly efficient production of new items with a minimum of waste. Moreover, some of the raw materials used in the production are discarded materials from other industries in Denmark, thus preventing waste.

\section{Lack of demand for certified circular products}

However advantageous this circular business model is both for the customers and for the environment, considerations of resource efficiency and environmental consequences of waste are not currently sufficient to drive GH Form's customers (primarily municipalities) to opt for a leasing model: $95 \%$ of the products are still being sold rather than leased. 


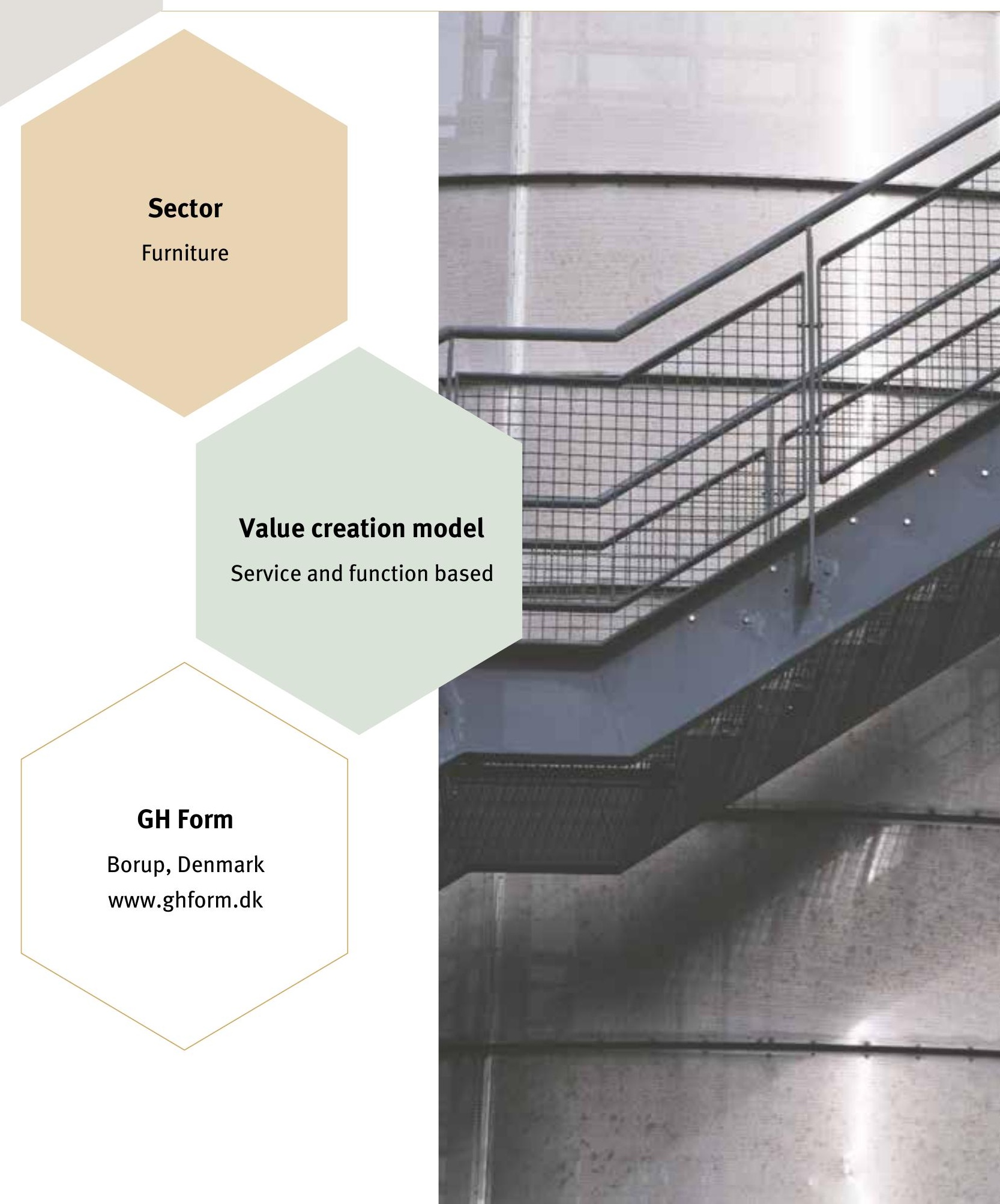




\section{Giving products new life in the cloud}

Swedish national Fredrik Östlin noticed that the distributed structure of many public sector organisations meant that excess furniture and other resources frequently went to waste simply through lack of awareness of their availability. With this in mind, he founded Off2Off, a web-based communication service initially for Swedish public sector organisations where supply and demand in goods and resources, such as furniture, office equipment, vehicles, electrical and electronic products can be matched, primarily within the organization.

This business model helps extending products' useful lifetime by creating new opportunities for their use, and thus follows the inner circle of the circular economy. Now public and private organisations use the service to exchange information about needs and functional surplus (things that are too good to be thrown away) both within their own organisations and with other organisations.
Furthermore customers may also advertise additional services such as transportation, repair and reconditioning. Quite often the service allows the funds used for the purchase of materials to stay within the sector.

\section{Managing resources made easy}

All customers have their own account and have access to the Off2Off web support. The service functions as an easy to use cloud-based service, compatible with any interface connected to the internet. This gives the customers the opportunity to check for the availability of goods at the same moment as the demand arises and to monitor any upcoming match. While other marketplace platforms exist, Off2Off offers a dedicated and tailored service with a knowledge building concept that reveals the organization's reuse-behaviour. Matching functional surplus with demand reduces the need for storage whilst saving natural resources and reducing GHG emissions. The concept also creates new job opportunities within the additional services for local companies and labor market policy activities.

\section{Business expansion}

Following the launch of the webbased communication service in 2011, the company participated in the business incubator Inova. In 2012, the City of Malmö signed a contract with Off2Off, for supporting and enhancing their internal reuse operations, via their on-line platform Malvin, which was launched in 2013. Ragn-Sells, a waste management, environmental services and recycling corporation operating in several countries has commissioned Off2Off to customize and operate a platform, for the easy turnover and reuse of products within the organisation. SÖRAB a regional waste disposal company signed a contract 2014 and the municipality of Upplands Väsby signed a contract 2015. Establishing internal systems for exchange provides such large corporations with a new means to trim operations. 


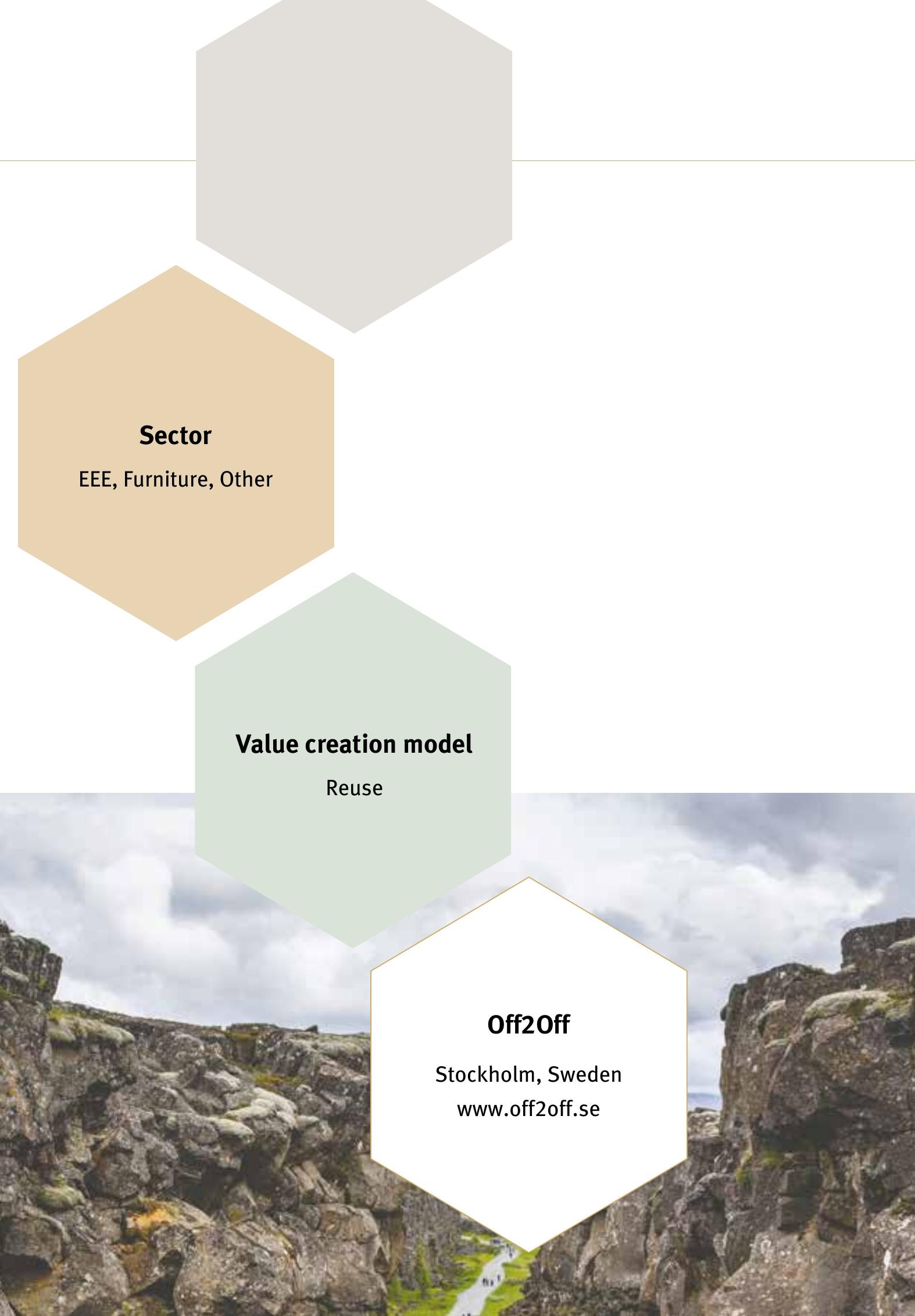


RePack is a sustainable packaging system for online retailers and shoppers. RePack's self-designed reusable packaging is easily returned through the postal system, and as a reward, users are offered RePack vouchers to other web stores. The scheme thereby encourages new sales and enforces consumer loyalty while reducing the amount of packaging waste.

Around 3.7 billion disposable packages are delivered to European E-commerce consumers each year, with most packaging discarded right away. RePack offers an easy option for reuse for environmentally conscious consumers who are willing to pay a premium where an upfront deposit is automatically refunded in the form of a voucher for the next e-commerce purchase. RePack packaging may be returned via the local postal system anywhere in the EU.

\section{A new perspective}

The founders worked on a sustainability project in Finland's Post Office, redesigning load carriers, when inspiration for a new system came from the returnable bottling systems in the Nordic Countries, which achieve very high return rates.

RePack's first customers were Finnish fashion web stores. Now RePack seeks to scale into international markets. In addition, RePack is using the home market to test how the concept can be expanded to other product categories such as e.g. pharmacy, food and electronics. Customer promise is that reusable packaging has several benefits over disposable packaging; it's easier to use, it reduces cost, creates value and removes trash.

\section{How it works}

The scheme is best illustrated with an example:

- Eva buys a new sweater from Globe Hope and chooses RePack delivery. She pays an extra fee of 3,90 EUR for reusable packaging.

- When Eva gets her RePack delivery she returns the empty RePack by dropping it into a postbox. Returning RePack is free for Eva.

- Once RePack is returned Eva is rewarded with a voucher for her next purchase. Voucher is emailed to Eva and it can be claimed at anhy RePack using store.

- RePack packaging is delivered to be reused at RePack using webstores. 


\section{Upcycling materials}

RePack's smallest packaging is designed from used and now upcycled advertising billboards. The medium and large packaging is made from more durable polypropylene.

RePack is designed to be used up to 20 times, with a carbon footprint four times smaller than regular packaging.

\section{Sector}

Packaging
Value creation model

Reuse 


\section{Plus Pack}

\section{Efficiency within plastic and aluminium packaging}

\begin{abstract}
A large proportion of food sold in Nordic countries comes in plastic and aluminium packaging produced by Plus Pack A/S. Through techno-logical advances and product development, Plus Pack A/S strive to minimize the use of resources and to cut down on waste.
\end{abstract}

\section{Reduction of impacts along the production chain}

Environmental impacts are saved both in the production of packaging and in its end-of-life phase. Down-gauging, development of thinner, lighter and stronger mate- rials and new alloys for packaging allows reducing resource and energy consumption for production. Moreover, all production cut-offs, be it aluminium or plastic, are re-melted and blended to the mixture for new products to prevent waste and save on raw materials expenses. Production technology is constantly refined to reduce production scrap, and energy efficient thermoformers have been installed.

Plus Pack $A / S$ also influences its suppliers, by asking for raw materials, products and services with low embedded energy. In this way, environmental impacts can also be saved earlier in the production chain.

\section{Innovative materials}

After an intensive two-year long effort in development of new packaging materials, Plus Pack achieved $11 \%$ reduction of total $\mathrm{CO}_{2}$ emissions on Portion Pack containers and a further decrease in raw materials consumption.

All plastic materials used for Plus Pack packaging can be recycled, and recycled materials are used in a 
number of their packaging products. Three materials in particular make a big contribution to the circularity of Plus Pack's business model:

1. Aluminium, as the material is $100 \%$ barrier efficient and $100 \%$ recyclable. Aluminium can be recycled an infinite number of times without loss of its essential properties.

2. Recycled rPET: makes up $50 \%$ of Plus Pack's plastic, and is expected to remain an attractive PET packaging material.
3. A fully recyclable PP chalk material made with a $100 \%$ natural mineral, calcium carbonate. The fact that $50 \%$ of this material is made of non-petroleum-based raw ingredients leads to $\mathrm{CO}_{2}$ reductions, energy savings and lower consumption of fresh water.

A number of other Nordic companies are also working to reduce waste, improve on materials and ensure closed loops. Amongst these are Norwegian Biobag and Swedish Ecolean.

\section{Plus Pack A/S}

Odense, Denmark

www.pluspack.com

Sector

Packaging

Value creation model

Product design 


\section{Circular ambitions}

Lassila \& Tikanoja is a large Finnish service company that works towards transforming the Finnish society into an efficient recycling society as part of a circular economy. Lassila \& Tikanoja was founded in 1905 as a wholesale business, but has now developed into an international corporation focusing on environmental management and support services for properties and plants. L\&T has business operations in Finland, Sweden and Russia. The company has 8000 employees and had a EUR 640 million turnover in 2014.

Lassila \& Tikanoja does not only manage waste, but also works toward reducing waste volumes, extending the useful lives of properties, recovering materials and decreasing the use of raw materials and energy. Lassila \& Tikanoja is part of a coalition comprised of non-profit organisations, business- es and public sector operators that have issued a shared statement calling for the circular economy to be included as one of the key objectives of the next Government Programme.

\section{Partners joining forces in order} to bring pallets into closed loop In the Nordic countries and in the EU, there is focus on increasing the reuse and recycling of packaging. Packaging has a central role in the consumer goods system and could be an evident case for introducing a circular business model.

Wood packaging like pallets could be of particular interest. In the current system most wood packaging is incinerated for energy recovery, but in order to improve on the recycling targets, which are expected to tighten, wooden packaging could be an evident case for increasing reuse and recycling.
In 2014 Lassila \& Tikanoja therefore acquired J A Tauriainen in order to internalize their successful operations with reuse and recycling of pallets. J A Tauriainen is located in Järvenpää, Finland and it is one of the leaders in the recycling and repair of pallets in Finland. The acquisition will make Lassila \& Tikanoja one of the largest operators in the field in Finland. Prior to the acquisition, J A Tauriainens had more than 20 employees and their net sales were around EUR 7 million. It expected that this acquisition will increase the reuse and recycling of wooden pallets significantly.

STEA which is located in both Denmark, Sweden and Germany also repair and reuse wooden pallets. 


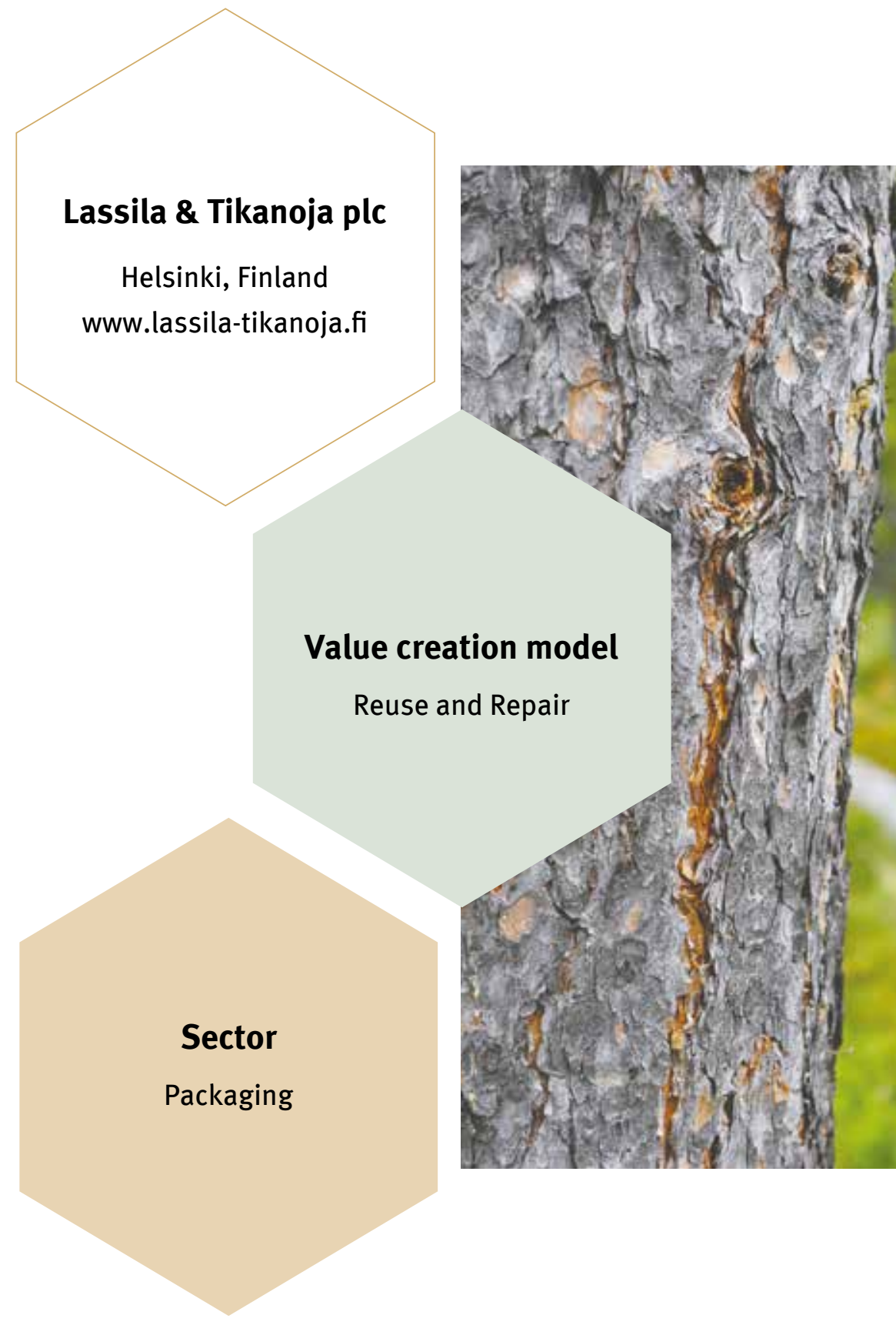


Swedish Blocket is an online secondhand marketplace. Henrik Nordström started it in 1996 as an online flea market for the Southern region of Skåne. However, after a few years, Blocket expanded nationwide, and today one may find almost anything on Blocket; from an inexpensive second-hand kitchenware to hundred thousand euro houses or a new job. In turn, Blocket earns revenue by charging a small fee per advertisement.

\section{Blocket by the numbers}

5 million people visit Blocket.se every week, making it Sweden's largest national retail market. 8 out of 10 swedes and 9 out of 10 Swedish families with children have bought or sold something on Blocket, and an incredible $99 \%$ of all swedes have heard about Blocket. In 2013 the total sum of for-sale item in ads was 414 bn Swedish kroner, which corresponds to around $11 \%$ of Sweden's BNP. These are large numbers. With expertise from Svenska Miljöinstitutet (IVL), an independent, non-profit environmental research institute, Blocket investigated the climate impact of second-hand trade. The results show that second-hand trade on Blocket is estimated to save 1.6 million tons of greenhouse gasses annually, corresponding to all road traffic in Stockholm in 18 months.

\section{Societal impact}

Blocket prides itself on societal responsibility. It adheres to the UN Global Compact, reduces the climate footprint through low energy business practices and climate compensation, spreads knowledge on sustainable consumption, and works with trademark representatives to avoid counterfeit goods on the marketplace, as they are rarely produced responsibly. Blocket also collaborates with Retoy, through financing, volunteering work and marketing, to create toy-swapping events where children may swap, borrow and create toys. Thereby through playtime practice sustainable consumption.

For its efforts, Blocket has been awarded a number of prizes, including 'Inspirationspriset' a prize for inspiring people to reuse products and a scholarship from Berghs School of Communication to pursue communication as a driver for sustainability.

\section{Brave new world}

Blocket is an example of circular economy thinking by encouraging people to prolong the lifespan of 
products and diverting them away from the buy-and-discard culture and lifestyles. ICT, allows easy and equal access for everyone with Internet all across Sweden $24 / 7$, with easy membership and payment schemes. The economics of online trade reduce transaction costs for the consumer and induce price mechanisms of demand and supply. The environmental benefit of utilising idle capacity of goods and unused services appeals to environmentally aware consumers, and an ethical movement of vintage and second-hand goods add extra value to Blocket services.

Blocket has expanded its concept to 40 countries, and similar on-line market places are seen in Norway (finn.no), Denmark (dba.dk and guloggratis.dk).

\section{Blocket AB}

\section{Stockholm, Sverige}

www.blocket.se

\section{Value creation model}

Collaborative consumption,

Reuse

\section{Sector}

\section{Consumer goods}




\section{Zen Robotics}

\section{Recycling at its best}

Although the Nordic region in general is well known for high quality and efficient waste management, there are still some steps to go in order to close the "outer" loops of the material cycles in the economy. Efficient sorting and recycling technology is just as relevant for the circular economy as business models for repair and reuse. Zen Robotics is a great example of such a technology.

\section{High-tech solution for sorting waste}

ZenRobotics Brain is a robot control technology developed by ZenRobotics. The advanced control system utilizes multiple sensor inputs in realtime, reacts to changes and learns from its mistakes. The sensors include various camera types (visible light, spectrometric cameras like NIR), 3D scanners, haptics, metal detectors etc. With enough sensors, ZenRobotics Brain can form a more comprehensive view of the waste stream than has so far been possible.

Robot arms sort out the most valuable pieces from the waste stream including rigid plastics. Using enormous amounts of sensor data, ZenRobotics Recycler can identify wanted items and raw materials from the waste stream and reclaim them for recycling. The ZenRobotics Brain is tasked with analysing and refining the sensor data into useful information using realtime data mining technology.

Currently, the Next Generation ZenRobotics Recycler can sort 3,000 picks per hour on average and the peak sorting speed is around 4,000 picks per hour. It can also pick heavier objects, up to $20 \mathrm{~kg}$, with a reach of 2 meters along the sorting belt.

\section{Award-winning technology}

In 2014 ZenRobotics was named in the prestigious 2014 Global Cleantech 100 as a world leader in robotic recycling systems. The Global Cleantech 100 represents the most innovative and promising ideas in cleantech. Featuring companies that are best positioned to solve tomorrow's clean technology challenges, and Global Cleantech 100 is a comprehensive list of private companies with the highest potential to make the most significant market impact. 


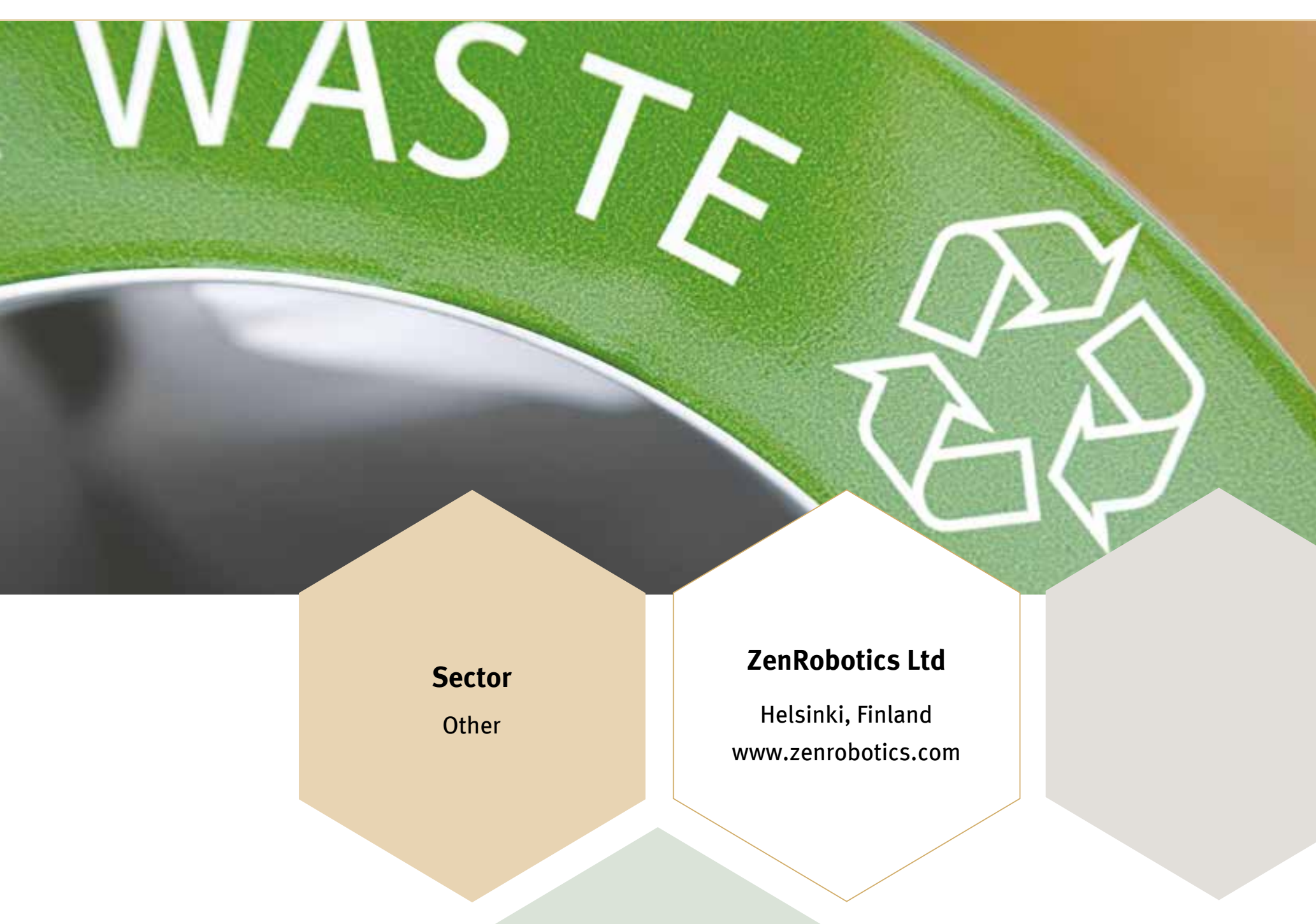

\section{Value creation model}

Recycling and

waste management 


\section{Norsk Gjenvinning}

\section{Putting strategy into practice by closing the waste loop}

Norsk Gjenvinning is Norway's leading waste management company providing waste- and recycling services for businesses, the public sector and private individuals with a turnover of more than 4 billion NOK and 1.400 employees. Their vision is to provide practical solutions that help customers achieve their goals within sustainability in general and proper waste management in particular. The aim is a business driven shift towards a circular economy where doing right for the environment also brings profitability. Norsk Gjenvinning seeks to work across sectors and in the full value chain to identify solutions that are positive for both society, environment and the economy.

\section{Circular economic projects in practice}

Within the past year, Norsk Gjenvinning has implemented various projects towards a circular economy:

- New technological developments and solutions have been developed for the recovery of sealed double glazed house windows. Such windows, containing PCBs and chlorinated paraffin's, were previously sent to Europe for incineration as hazardous waste. Along with Glava (Norway's largest producer of insulation material) Norsk Gjenvinning has developed a glass crushing plant to allow waste window glass directly into production of Glava insulation products. Glava previously imported equivalent amount glass from Europe, but can now use recycled material.
- Together with Norsk Hydro (Word leading aluminum producer) and Nespresso, Norsk Gjenvinning has developed a solution for recovering Nespresso coffee capsules in Norway. From the end of 2015 Nespresso capsules from Denmark will also be recovered. The solution ensures a transition from incineration to $100 \%$ material recycling. Coffee grounds is turned into biogas and aluminum is recycled into new aluminum through Hydro's smelter in Norway.

- Norsk Gjenvinning has also worked with $R \& D$ institutions, the boating industry, consultants and governments to introduce a solution for recycling of leisure boats (ELB). Engaging the industry side, Norsk Gjenvinning has called for action, both to secure key resources and reduce a growing environmental problem of yachts being disposed of in nature. 


\section{Sector}

- Amongst their activities, Norsk Gjenvinning also participate in forums and think-tanks that touch upon the theme of circular economy. A few examples are:

- Norsk Gjenvinning are McKinsey \& Co.'s selected partner to help analyze and explain the circular economic potential in Norway. During 2015 selected industrial companies, NGOs, governments, etc. will be invited for verification and further development of circular business models. The work is based on the methodology and analysis that McKinsey \& Co. has previously provided for the Ellen MacArthur Foundation.

- Norsk Gjenvinning, SoCentral and Innovation Norway will establish a corporate network that will focus on circular economic growth opportunities.

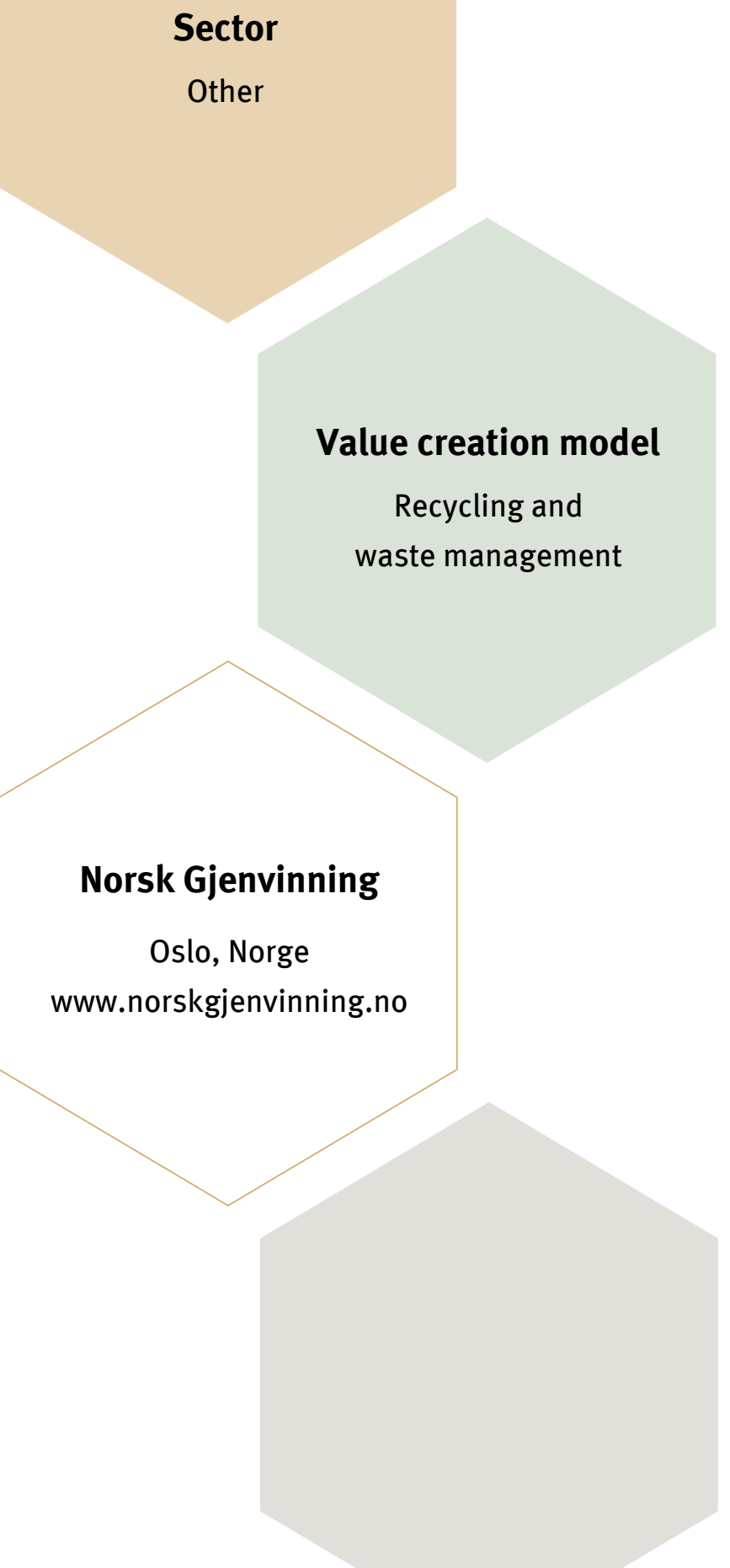




\section{The workshop}

The workshop on April 28th in Copenhagen brought together a mixed range of people from businesses, knowledge institutions as well as public and private organisation to discuss opportunities for facilitating the proliferation of circular business models (see invitation and participation list in Annex 1 and 2 respectively). The aim of the workshop was to provide the Nordic Council with specific policy messages and recommended actions that could support and promote circular business models.
The workshop was built up by a mix of inspiring presentations and panel discussions combined with participatory innovation labs and sector labs. In the innovation labs discussion focused on characteristics, trends and opportunities for six types of business model elements were discussed: Product design, Service- and function based models, Collaborative consumption, Reuse, Repair, as well as Recycling and waste management. In the sector labs, the workshop focused on six specific themes: Textiles, WEEE, Furniture, Food, Packaging, and Construction. As part of the workshop documentation, eighteen examples of companies already engaged in circular business models were presented. In addition, a selection of prominent speakers presented the latest insights on the circular economy from both within and outside the Nordic region. These inputs, as well as each of the participants' expertise, provided great inspiration for the discussions, and also caused some debate about the nature of circular business models. The workshop discussions proved both provocative and fruitful: participants were engaged, and were eager to both learn about and influence the future direction of circular economy initiatives in the Nordic region. 


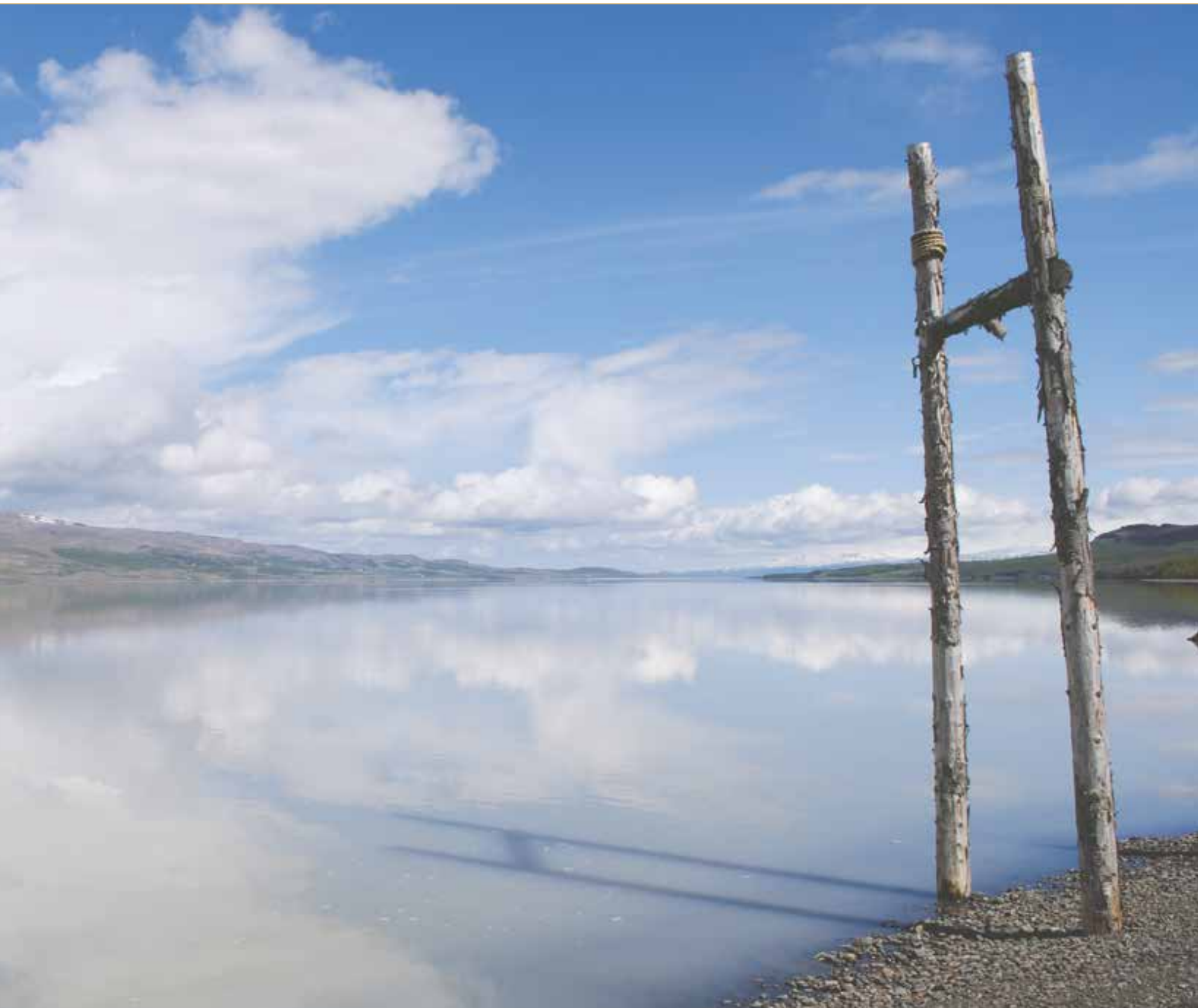

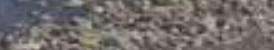

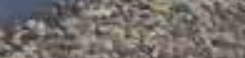

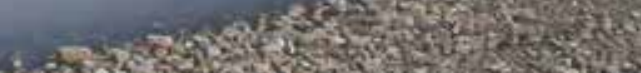

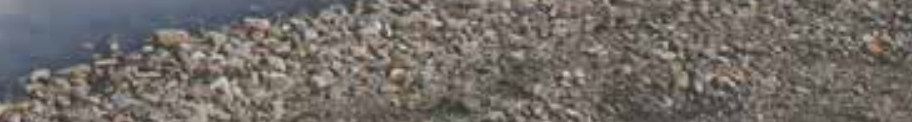

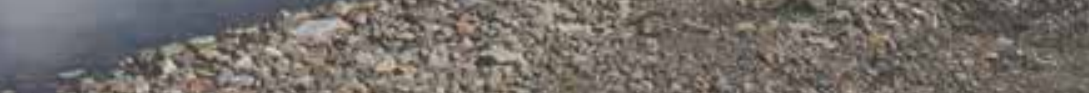

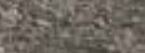




\section{Key Findings}

\section{General policy messages}

Although discussions were wide ranging, it was clear that there were also some common threads, which applied across several of the sectors:

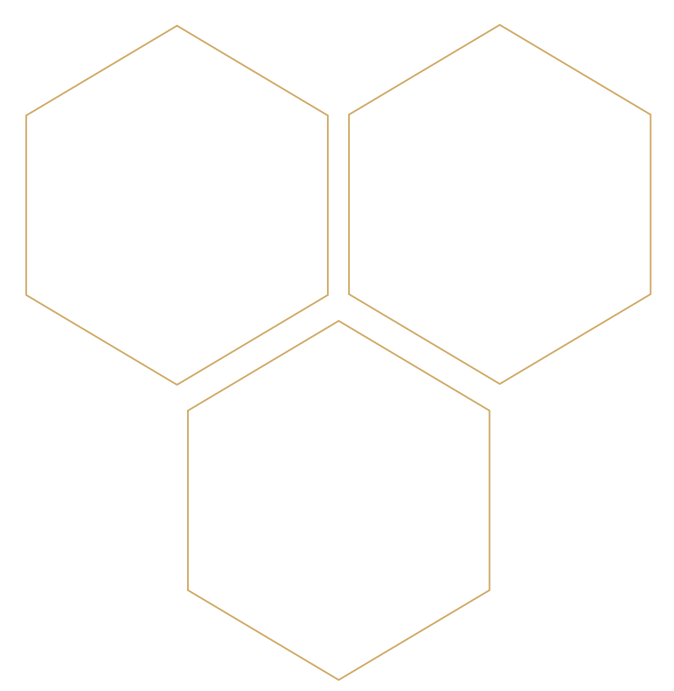

\section{Better design and stronger markets}

For consumer goods like textiles, WEEE, furniture, packaging as well as certain construction materials, design for long life, including reuse and repair, is crucial in order to ensure circular economic business models. Products and materials must therefore be designed and produced with longevity and proper end-of-life handling in mind, in order to make the circular economy work. It was, however, underlined that a crucial prerequisite for these improvement in design was the presence of a market for them. Thus, creating markets, whether it being by public or private demand, is essential. This was also underlined with respect to markets for better designed products, reuse, repair and service- and function based busi- ness models. One powerful driver for market creation can be public procurement by e.g. including criteria on expected active lifetime, options for upgrading and/or customising as well as reparability in procurement practices. In this respect, public bodies and organisations could also implement guidelines for the handling of used equipment (such as IT, uniforms, furniture and buildings) in order to ensure alignment with the waste hierarchy and circular economic practices. Reuse and repair markets could be strengthened by the introduction of certification of reused or repaired products. This would help alleviate buyers' and consumers' concerns over quality and expected lifetime of used products. 


\section{Setting (ambitious) re-use target}

Setting reuse targets could be used to drive reuse in the Nordic countries. For example, Spain is the first European country to introduce a separate national quantitative target for preparation re-use of certain WEEE categories: $2 \%$ of large household appliances and 3\% of IT equipment must be prepared for re-use from 2017, and from 2018, the targets will rise to $3 \%$ and $4 \%$ respectively (Boletín Oficial Del Estado, 2015). Similarly, France has set a reuse target to increasing the amount of used furniture put back on the market: by $50 \%$ from baseline by 2017 . This target has been framed in the context of a national EPR scheme for domestic and professional furniture (Legifrance, 2012), which ensures that social enterprises are granted access to collection points in order to carry out reuse activities. 


\section{Increasing levels of repair}

Increasing the level of repair was also a general theme heard across the tables at the workshop. Amongst other things, it was suggested to:

- Include specific requirements for reparability of products in the European Eco-Design Directive,

- Promote longer product warranties. This could be achieved by instituting a VAT reduction on all products with warranties longer than the legally required minimum.

- Introduce instruments or models that can support or partially finance salaries for repair. This could be achieved via increased focus on and establishment of social enterprises.
- Ensure better information and education on how to repair products and where to find spare parts. In this respect, the Nordic countries could be inspired by French law, where manufacturers have to clearly label products with information about how long spare parts will be available (Legifrance, 2014). This law is part of a larger programme on planned obsolesce which was decided upon in March 2014.

\section{More and better communica- tion and transparency}

Communication and transparency in the entire value chain was also perceived as crucial. Environmental (and economic) benefits should be clear, and should be communicated to all stakeholders in order to facilitate environmentally better choices. Further, good case studies and best practice examples should be collected and spread in order to inspire and create dialogue. A "circular economy mentor scheme for SMEs" was suggested as a way to particularly target this group in the business community. Finally, information and dialogue in schools, business communities, to the general public was considered as a basic step for not only creating structural change, but also bringing about a more fundamental cultural change toward circular economy thinking, which was considered necessary. 


\section{Sector-specific recommendations}

Participants were also vocal on the challenges and opportunities within their specific sector. The key policy messages from these discussions were:

\section{Textiles}

There is an evident case for the development of new business models within textiles, and much is already happening in the area. However, some people do not like concept of using clothing which someone else has used. There might therefore be a need for rendering the previous user invisible by presenting shops and clothes clean and "fresh", removing the notion of "second hand". In order to promote the circular business models, VAT exceptions for new business models should be considered. Further, an import duty on volume rather than on value was suggested as a driver for better quality products.

The content of hazardous substances in textiles was also discussed, and either a ban on use of high concern substances or taxation of textiles of concern or containing high concern substances on the EU level was suggested as a way forward. This might also ease recycling, which is currently considered an important area to explore further. Funding and research into more and better recycling was therefore also considered necessary. Finally, as has already been explored by the Nordic Council of Ministers, an EPR scheme for textiles was suggested.

\section{(W)EEE}

EEE is an evident case for improving product design, making EEE products more suitable for reuse, repair and better waste management. However, in order to create substantial basis for these types of business models, efficient and well-functioning take-back- and collection systems are decisive. Particular focus was therefore put on ensuring better logistic and take-back systems. A large proportion of discarded EEE is still fully functional, and suitable for reuse and/or preparation for reuse, 
but unfortunately, current logistic systems are not designed to protect and safeguard these valuable resources. Thus, much fully functional used EEE is handled as waste and damaged and sometimes also stolen. Nordic EEE handling systems should therefore be improved in order to prevent damage, but just as importantly, to prevent theft of valuable products and resources. Later, in the closing session it was stressed that well-functioning and suitable take-back systems are not only relevant for (W)EEE sector but also for other products like textiles, furniture, packaging and C\&D materials.

\section{Furniture}

Participants in the furniture group concluded that there is a solid case for developing CE business models - particularly in markets for business to business (B2B) trade (office furniture for example) where larger "batches" of relatively homogenous furniture are handled. In this respect, public procurers could play a role in pushing the market for service- and function based models, as well as creating markets for reuse. It was underlined that producers and procurers need to collaborate in order to ensure that products are designed for reuse, for customising and retrofitting, for long life, for repair and for disassembly.
It was also recommended that governments set certain requirements for reuse of furniture. This could involve municipalities and/or waste handlers or alternatively, as was mentioned above, social businesses, as seen in France.

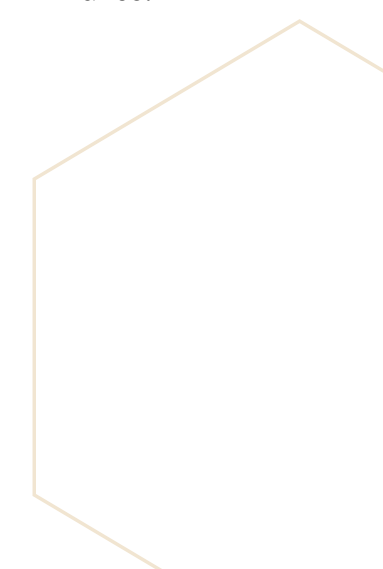




\section{Packaging}

It was recommended that an increased general focus is put on reusable packaging in all parts of the value chain, but particularly within the $B 2 B$ market. Much of the packaging currently being used is solelv for one-way use, after which it is often not suitable for recycling. Shifting the consumer goods packaging industry to circular models can result in significant material savings. In order to obtain true circularity, it is necessary that packaging is designed for both durability and reuse as well as for recycling.

\section{Food}

Circular economic thinking around food is somewhat different from other types of products. Since food is a one-way consumable product. Reusing or repairing does not really apply! Instead, other types of opportunities, like waste prevention and developing production processes that include elements of CE, are more promising. In particular, the participants at the workshop discussed how to better make use of already produced food and thus to prevent food waste. This could mean launching specialised stores for dated food and food with damaged packaging, inspired by social super- markets in Austria and England. In some cases, this might require an easing of regulation related to food safety. Further, it was also discussed how the public can participate in food sharing and food collectives, which can be facilitated via new types of media such as social media groups and related apps. Finally, it was discussed how to improve and perhaps shorten the supply chain. One referred to the European BERAS project, which provides recommendations for developing a realistic, fully integrated ecological alternative, producing a systemic shift in the food chain from farmer to consumer. 


\section{Construction}

The table discussions focused on one of the bigger challenges with C\&D materials and waste: that the Nordic building stock tends to be relatively old, which means that demolition and proper material handling can be challenging in terms of problematic and/or unknown content of substances. In order to overcome these challenges in the future, is was suggested to conduct careful "mapping" of all content in new buildings, in order to prepare for proper handling according to $C E$ principles. Further, it was suggested that a tax reduction could be imposed on "sustainable buildings" that carry international certification like the Nordic Swan ${ }^{1}, \mathrm{C}_{2} \mathrm{C}^{2}$ or the
BREEAM ${ }^{3}$ system. A scarcity tax on new $\mathrm{CO}_{2}$-intensive materials was also discussed as a means of promoting better and more environmentally friendly design.

1 The Nordic Ecolabel is a voluntary ecolabelling scheme that evaluates a product's impact on the environment throughout the whole life cycle. See www.nordic-ecolabel.org

2 The Cradle to Cradle Certified ${ }^{\mathrm{TM}}$ Product Standard guides designers and manufacturers through a continual improvement process that looks at a product through five quality categories - material health, material reutilization, renewable energy and carbon management, water stewardship, and social fairness. See www.c2ccertified.org

3 BREEAM is the world's leading design and assessment method for sustainable buildings. BREEAM can be used to assess the environmental performance of any type of building, new and existing, anywhere in the world. See www.breeam.org 


\section{Panel discussion}

The closing panel discussion outlined and summarised some more general discussion threads. It was first and foremost underlined that, no matter how policy makers choose to proliferate circular economy in the Nordic countries, clear and predictable legislation is essential for the business community to respond in a desirable way. Simple and long-term objectives and regulation that level the playing-field are thus crucial. Ultimately, some clear recommendations for the Nordic Council of Ministers were laid out:
- Identify sectors or areas that are most relevant for circular economic business models.

- Demonstrate incentives (monetary as well as non-monetary) which can pull (rather than push) development towards a circular economy.

- Explore and develop National Capital Accounting (an extension of the work undertaken by Novo Nordisk and the Danish apparel sector in collaboration with the Danish EPA) in order to "get the prices right".
Explore the possibilities of re-defining end-of-waste criteria in European legislation in order to ease possibilities for reuse, repair and refurbishment.

- Unite and spread the voice of the Nordic countries, and work on common positions formulated via clear messages. 


\section{Dansk sammenfatning}

Den cirkulære økonomi står højt på den politiske dagsorden. Globale erhvervsledere, politikere, akademikere og NGO'er fastslår, at udviklingen mod en mere cirkulær økonomi er nødvendig, hvis de globale miljømæssige og økonomiske udfordringer skal løses. I tillæg har den Europæiske Kommission forpligtet sig til at præsentere en revideret og mere ambitiøs strategi for cirkulær økonomi inden udgangen af 2015.

Mange har understreget nødvendigheden af en cirkulær økonomi, men især Ellen McArthur Fonden har været toneangivende. Ifølge fonden er den nuværende lineære økonomiske model uholdbar, idet den hovedsageligt er baseret på en "forbrug-og-smid-væk" kultur, der medfører en række udfordringer, herunder bl.a. en bevægelse mod kortere produktlevetid samt en tendens til at produkter bortskaffes frem for at blive repareret, til trods for, at reparation er en reel mulighed. Den lineære model medfører således ineffektiv udnyttelse af klodens sparsomme ressourcer, øgede mængder skadelige emissioner samt stigende mængder affald.

Ellen McArthur Fonden beskriver den cirkulære økonomi som et system der er designet med henblik på at reducere og i sidste ende helt fjerne spild ved hjælp af bedre design af materialer, produkter, systemer og forretningsmodeller. Ud over en langt mere effektiv udnyttelse af ressourcerne, herunder altså også reduktion eller måske en fuldstændig eliminering af de negative konsekvenser af affaldsgenerering, forventes den cirkulære økonomi endvidere at skabe arbejdspladser. Potentialerne i den cirkulære økonomi er således betydelige.

\section{De nordiske virksomheder er allerede i gang}

Den nordiske gruppe for affaldsforebyggelse under Nordisk Ministerråd igangsatte derfor projektet "På vej mod den cirkulære økonomi - succesfulde nordiske forretningsmodeller”. Målet med projektet var at øge kendskabet til principperne bag cirkulær økonomi generelt, samt at fremme udviklingen inden for cirkulær økonomi i de nordiske lande, gennem præsentation af en række eksempler på succesfulde nordiske forretningsmodeller samt afholdelse af en workshop for interessenter med repræsentation af både erhvervsfolk, embedsmænd, forskere og NGO'er. Resultatet 
er nærværende publikation, hvor cirkulære forretningsmodeller fra 18 nordiske virksomheder er præsenteret sammen med en række af de mest fremtrædende resultater og anbefalinger fra workshoppen.

Mange store virksomheder i de nordiske lande har nu taget ambitiøse og vigtige skridt i retning af mere cirkulære forretningsmodeller, mens mindre, og undertiden mindre kendte virksomheder, allerede udøver cirkulær økonomi i praksis. Fokus har været på at præsentere virksomheder fra både Sverige, Norge, Finland, Danmark og Island, som bredt dækker de seks udvalgte fokusområder: Fødevarer, tekstiler, elektrisk og elektronisk udstyr, bygge- anlæg, møbler samt emballage.
Virksomhederne er hovedsageligt små- og mellemstore virksomheder, der alle opererer inden for et eller flere af de seks områder, som har været i fokus for projektet: Produktdesign, service- og funktionsbaserede modeller, deleøkonomi, genbrug, reparation samt genanvendelse og affaldshåndtering. Målet er, at kataloget skal inspirere og opfordre andre virksomheder til at tage kreative og innovative skridt i samme retning.

\section{Konkrete forslag til handling}

På workshoppen, som blev afholdt i København den 28. april 2015, blev både forskellige typer af forretningsmodeller og forskellige områder og sektorer diskuteret (se program og deltagerliste i henholdsvis Annex 1 og 2). Gruppedannelser med forskellige interessenter medførte en række forskelligartede ideer og anbefalinger som retter sig mod både regeringer, producenter og andre aktører. De mest fremtrædende budskaber, som gik igen blandt deltagerne var, at regeringer:

- generelt introducerer enkel og langsigtet regulering således, at aktørerne kan operere på lige vilkår;

- indfører mål for genbrug,

- understøtter bedre kvalitet i genanvendelse,

- anvender offentlige indkøb som et redskab til at skabe markeder og efterspørgsel efter cirkulære forretningsmodeller,

- sætter lovmæssige krav til mulighederne for at reparere, kræve længere garantiperioder samt bedre information om eksempelvis tilgængelighed af reservedele. 
Ydermere var der generel enighed

om:

- at producenter bør påtage sig ansvar for at udbyde produkter med lang levetid, som fremmer genbrug og reparation,

- at et certificeringssystem for genbrugte og reparerede produkter vil understøtte markedet for disse produkter,

- at bedre kommunikation og gennemsigtighed ved hjælp af eksempelvis best-practice kataloger bør udarbejdes, samt
- at mentorordninger og øget dialog generelt vil være med til at afhjælpe den mangel på viden og information som der syntes at være omkring principperne for cirkulær økonomi.

Endelig blev det anbefalet, at Nordisk Ministerråd skal:

- identificere sektorer og områder inden for hvilke den cirkulære økonomi vil være relevant i en nordisk kontekst,

- gennemføre analyser der kan demonstrere effekterne af incitamenter (monetære såvel som ikke-monetære) som kan være med til at fremme udviklingen mod en cirkulær økonomi,
- undersøge og udvikle konceptet omkring National Capital Accounting så markedet sender de "rigtige" prissignaler,

- undersøge mulighederne for at redefinere end-of-waste kriterierne i den europæiske lovgivning, således at betingelserne for genbrug, reparation og genfremstilling lettes, samt endelig,

- at koordinere og fremme fælles Nordiske budskaber på en klar og entydig måde, med henblik på at påvirke eksempelvis den europæiske udevikling inden for miljø og cirkulær økonomi. 


\section{References}

\section{Boletín Oficial Del Estado (2015):}

1762 Real Decreto 110/2015, de 20 de febrero, sobre residuos de aparatos eléctricos y electrónicos, http://www.boe.es/boe/dias/2015/02/21/pdfs/BOE-A-2015-1762.pdf

\section{Legifrance (2012):}

Décret $\mathrm{n}^{\circ} 2012-22$ du 6 janvier 2012 relatif à la gestion des déchets d'éléments d'ameublement

http://www.legifrance.gouv.fr/affichTexte.do?cidTexte=JORFTEXT000025114585\&categorieLien=id

\section{Legifrance (2014):}

Décret $n^{\circ} 2014-1482$ du 9 décembre 2014 relatif aux obligations d'information et de fourniture concernant les pièces détachées indispensables à l'utilisation d'un bien, http://www.legifrance.gouv.fr/affichTexte.do?cidTexte=JORFTEXT000029881868\&dateTexte=\&categorieLien=id 


\section{Annex}

\section{1 - Workshop programme}

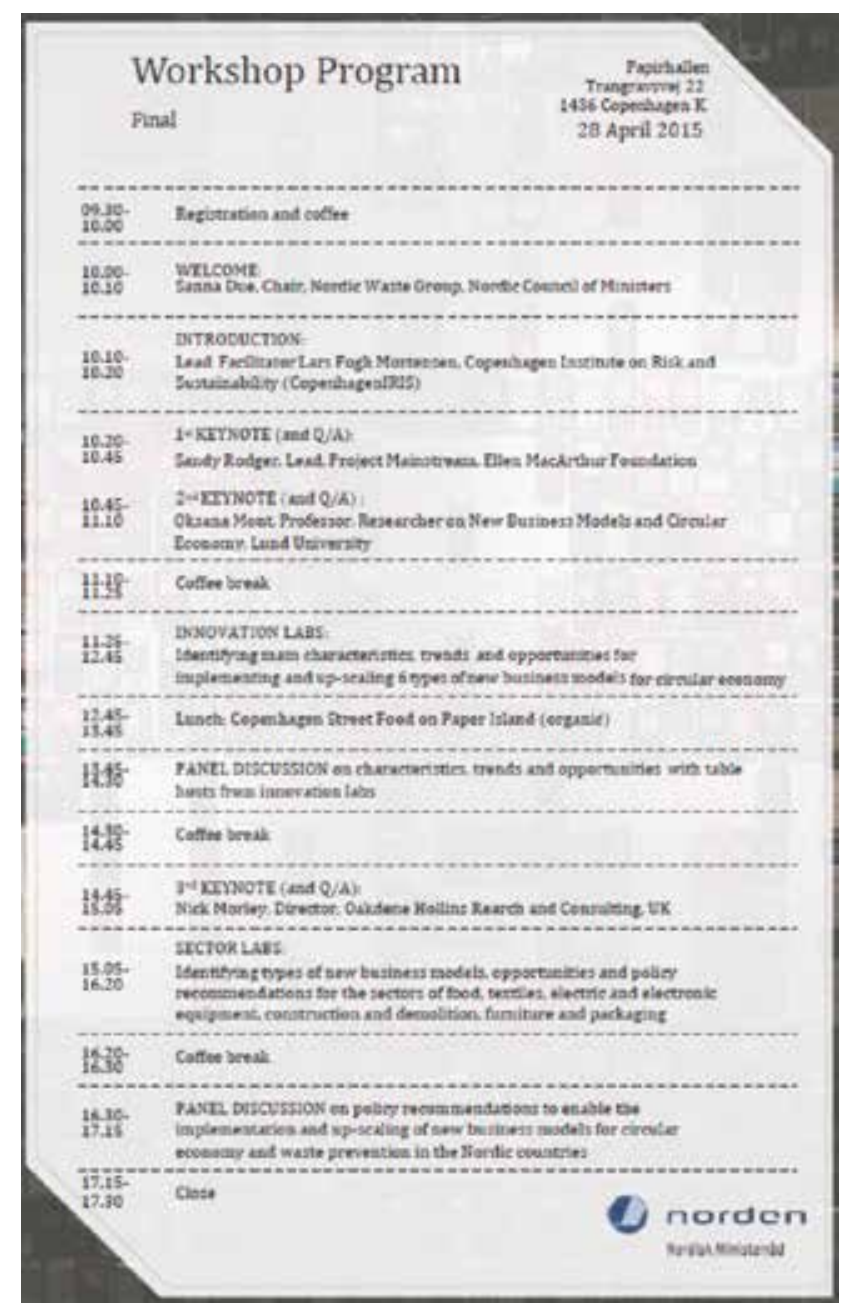




\section{2 - List of participants}

\begin{tabular}{|c|c|c|c|}
\hline Company or organisation & Country & Company or organisation & Country \\
\hline Ace \& Ace & DK & Ministry for the Environment and Natural Resources & IS \\
\hline AU Herning, Greenhouse & DK & Ministry of the Environment and Energy & SE \\
\hline BMH Technology & $\mathrm{FI}$ & NCC Recycling & SE \\
\hline Bæredygtigt Erhverv & DK & Nordic Council of Ministers & \\
\hline CHARE, Danish Refugee Counsil & DK & Norsk Gjenvinning & NO \\
\hline Copenhagen Resource Institute & DK & Norsk ombruk AS & NO \\
\hline CopenhagenIRIS & DK & Norwegian Environment Agency & NO \\
\hline DanDrone & DK & Oakdene Hollins / Centre for Remanufacturing and Reuse & EN \\
\hline Danish EPA & DK & off2off & SE \\
\hline Danish Federation of SMEs & DK & PlanMiljø & DK \\
\hline Danish Industry (DI) & DK & Radikale Venstre & DK \\
\hline Digipolis Oy & $\mathrm{FI}$ & REALLY ApS & DK \\
\hline Ekokem Group & $\mathrm{FI}$ & Resecond & DK \\
\hline Ellen MacArthur Foundation & UK & Ronneby Kommun & SE \\
\hline Esam AB & SE & roofurb & DK \\
\hline European Environment Agency & DK & School of engineering and social sciences & $\mathrm{Fl}$ \\
\hline Finnish Environment Institute & $\mathrm{FI}$ & SE Big Blue & DK \\
\hline Galaxe A/S - Thermozell Denmark & DK & Sitra & $\mathrm{FI}$ \\
\hline Green Transition Fund, Danish Business Authority & DK & Sustainable Leadership Lab & SE \\
\hline HRG NORDIC & DK & SUSTAINIA & DK \\
\hline IBM & $\mathrm{SE}$ & Swedish EPA & $\mathrm{SE}$ \\
\hline IKEA Denmark & DK & Swedish Waste Management & SE \\
\hline IKEA Norway & NO & Tarkett AB & SE \\
\hline IKEA Sweden & $\mathrm{SE}$ & VELUX Group & DK \\
\hline Innovationshuset & DK & Viktoria Swedish ICT & SE \\
\hline Inrego AB & $\mathrm{SE}$ & Worldperfect & DK \\
\hline Lund University & $\mathrm{SE}$ & WorldWatch Institute Europe & DK \\
\hline Mepex Consult AS & NO & & \\
\hline
\end{tabular}




\section{norden}

Nordic Council of Ministers

Ved Stranden 18

DK-1061 København K

www.norden.org 